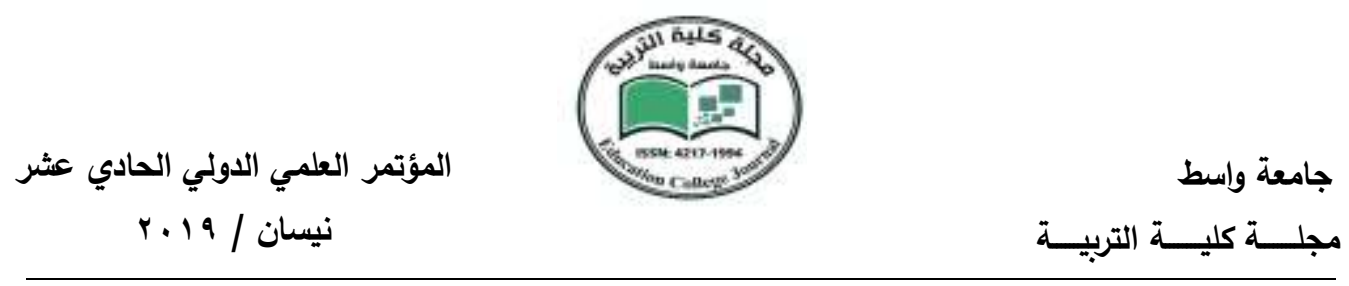

\title{
التلوث السمعي في مدينة بغداد (جانب الرصافة انموذجا)
}

م.د يونس كامل علي التي

جامعة ذي قار/كلية التربية للعلوم الانسانية

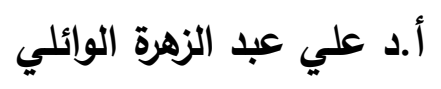

جامعة بغاد/كلية التربية (ابن رشد) للعوم الإنسانية

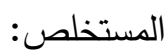

لقد تم اختيار (ץ • ()) موقع لرصد الضوضاء في جانب الرصافة في مدينة بغداد لأنشطة ومواقع

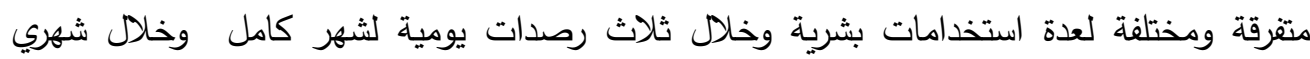

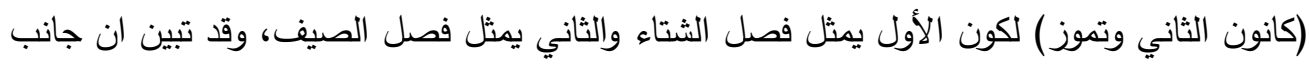

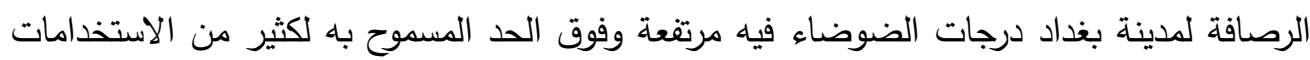

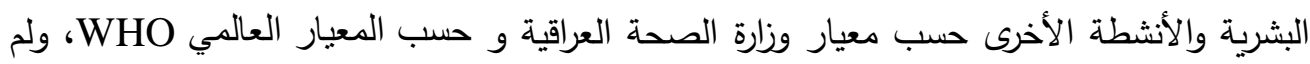
يتم رصد مستويات ضوضاء مقبولة سوى لبعض الرصدات المسائية لبعض الأستخدامات التعليمية،

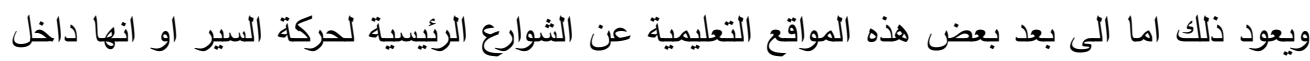

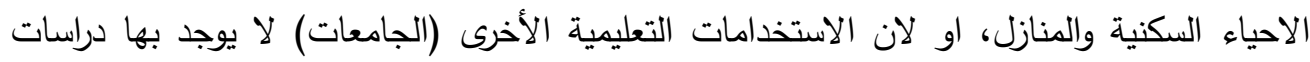

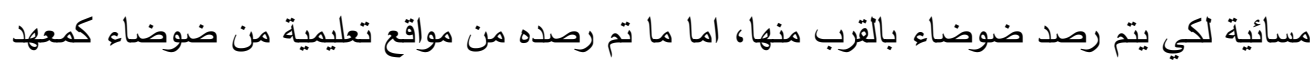

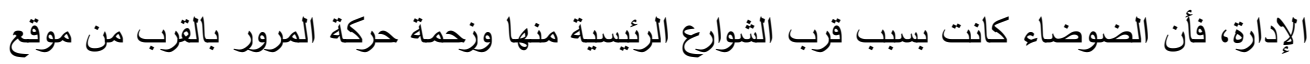

المقدمة:

ان مشكلة التلوث الضوضائي من المشاكل التي يعاني منها العالم الحديث المتطور والتي لا

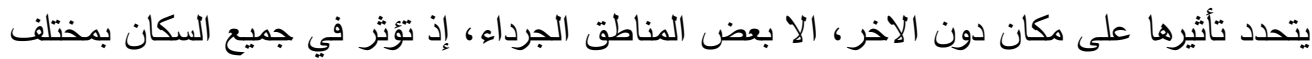

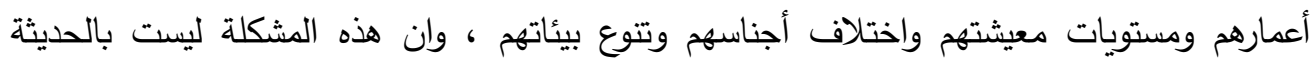

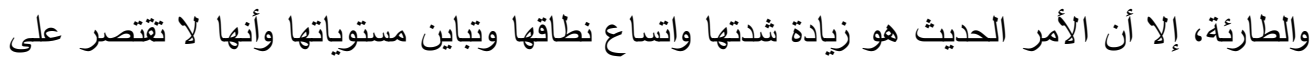

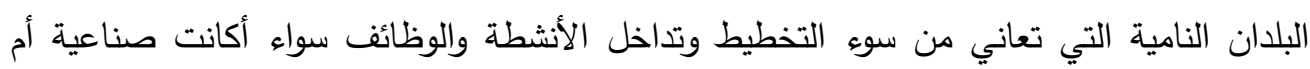

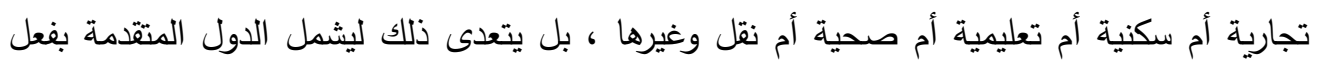
تقدم وتطور الصناعة وأتساع التبادلات التجارية.

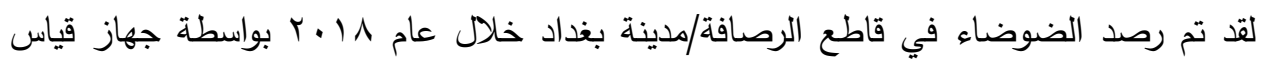

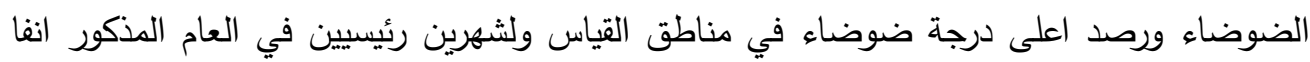


المؤتمر العلمي الاولي الحادي عثر

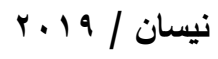

جامعة واسط

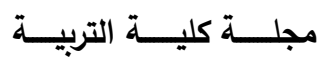

وهما شهري (كانون الثاني و تموز) وفي كل شهر مما ذكر تم رصد الضوضاء لــ(r · () موقع

جغرافي مختلف التوزيع في قاطع الرصافة لرصدتين احدهما (9) صباحا و (9) مساءا في الأيام العشرة الأولى من شهري كانون الثاني وتموز والأيام العشرة الثانية والأيام العشرة الثالثة ولرصدتين صباحا ومساءا لكل موقع من المواقع الــ(r • ()، وقد تم الرصد على مسافة (1-r)متر من مناطق الرصد المعينة في منطقة الدراسة.

أر/ارصدة الساعة التاسعة صباحا لقياس التلوث الضوضائي في جانب الرصافة لمدينة بغداد في

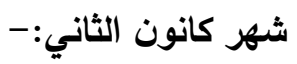

أولا: التحليل المكاني والزماني للتلوث الضوضائي لأغلب تقاطعات الطرق في جانب الرصافة في مدينة بغداد حسب استعمالات الأرض في شهر كانون الثاني:يتبين من الجدول (1) ان مستوى الضوضاء في اغلب تقاطعات الطرق الرئيسية لقاطع الرصافة لمدينة بغداد في شهر كانون الثاني للرصدات الثلاثة للضوضاء فوق الحد المسموح به حسب المعيار العالمي والمحلي لمستوى الضوضاء كما هو موضح في الجداول (r) و (r)؛ ، وعدت اكثر تقاطعات الطرق تلوثا ضوضائيا في قاطع الرصافة هم (الخلاني، تقاطع الوثبة، تقاطع النهضة) كون هذه هوض المناطق تعد مناطق مركز قاطع الرصافة وأيضا مراكز تجارية وتسويقية قرببة جدا منها وقد تم رصد الضوضاء على بعد (1-r)متر عن مركز التقاطعات الرئيسية في قاطع الرصافة، وبالتدريج حتى تصى

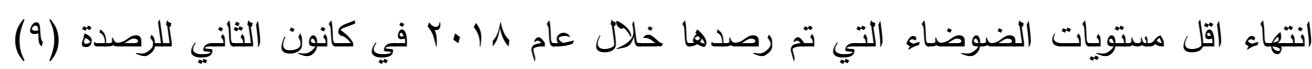
صباحا لثلاث رصدات في الشهر كانت لتقاطعات (مدينة الطب، والمهندسين) وذلك بسبب انتظام المراقبة المرورية وتتظيم السير في هذه المناطق، وعلى الرغم من احتلال المناطق الأخيرة التسلسل الأخير من حيث الضوضاء ولكنها مرتفعة أيضا بالنسبة للمعيار العالمي والمحلي للضوضاء. 
المؤتمر العلمي الدولي الحادي عثر

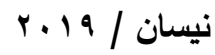

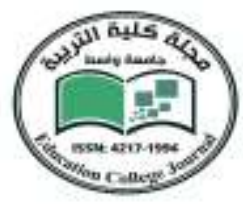

\section{جامعة واسط}

مجلــــة كليـــــة التربيــــة

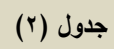

رصدة التاسعة صباحا خلال شهر كانون الثاني لأغلب مناطق عبور

الجسور في قاطع الرصافة

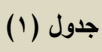

رصدة التاسعة صباحا خلال شهر كانون الثاني لأغلب تقاطعات الطرق في قاطع الرصافة

\begin{tabular}{|c|c|c|c|c|c|c|c|c|c|}
\hline 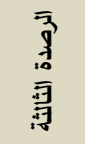 & 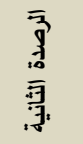 & $\begin{array}{l}\overline{3} \\
\text { 1. } \\
\overline{3} \\
\text { วิ }\end{array}$ & اسم الموقع & $ت$ & $\begin{array}{l}\overline{3} \\
\text { 豆 } \\
\text { 牙 }\end{array}$ & 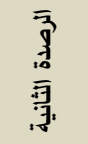 & $\begin{array}{l}\overline{3} \\
\overline{1} \\
\overline{3} \\
\overline{3}\end{array}$ & اسم الموقع & ت \\
\hline VA.r & VV. 9 & vo.r & المثنى & rr & vV.1 & Vo. $T$ & vo & مطعم الامير & 1 \\
\hline $79 . r$ & VY.r & vi.l & الصرافية & rr & Vo.r & V..1 & vч.r & شارع الصحة & r \\
\hline vo.1 & $V \leq .0$ & $V r . \varepsilon$ & باب المعظم & $r \leq$ & $\vee \wedge .9$ & 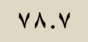 & V^.r & جامع النداء & $r$ \\
\hline VA.r & VV.r & Va.1 & السنك & ro & Al.r & A..r & Va.r & تقاطع الموال & $\varepsilon$ \\
\hline$v 1.1$ & Vo.r & VY.I & صليخ & rq & Vr.r & VT. 纟 & VY.r & ساحة بيروت & 0 \\
\hline$V \cdot . r$ & 79.1 & r..r & بغداد الف دار & rV & $\Lambda \varepsilon .7$ & Ar.o & Ar.r & مول النخيل & 1 \\
\hline VY.I & VT.O & VT.E & ابونؤاس/المنصود & $r \wedge$ & Vq. & VV.Y & Vq.r & الباب الشرقي & v \\
\hline Vr.l & Vr.l & $v \varepsilon$ & الثعب & rq & จ^.r & $\wedge .$. & va.r & باب المعظم & $\wedge$ \\
\hline$v \cdot . r$ & VY.I & vi.r & البنوك//الوزيرية & $r$. & V9.9 & Al.r & A. .r & تقاطع النهضة & 9 \\
\hline & & $(r)$ & & & VV.r & V^.r & Vq.r & سوق الحي & 1. \\
\hline ناعية في & ل الأحيا: & رافة الثاني & عة صباحا خلال شهر & رصدة أ & $v \cdot . \varepsilon$ & $v \ldots r$ & VY.Y & المهندسين & 11 \\
\hline 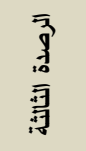 & $\begin{array}{l}\overline{3} \\
7 \\
10 \\
\overline{3} \\
\overline{7}: \overline{7}\end{array}$ & $\begin{array}{l}\overline{3} \\
\text { द⿱ } \\
\overline{10} \\
\overline{3}\end{array}$ & اسم الموقع & $ت$ & $1 \cdot r .0$ & QV.r & $90 . r$ & الخلاني & ir \\
\hline$V \varepsilon . r$ & $V \varepsilon . r$ & vo.1 & بغداد الجديدة & $m$ & $91 . r$ & $\wedge \wedge . r$ & ^৭. & ساحة الوثبة & Ir \\
\hline$v \cdot . q$ & VY.I & $v \leqslant .1$ & شيخ عمر & rt & $\vee \wedge .1$ & $\vee \wedge . r$ & Va.r & سينما البيضاء & $1 \leqslant$ \\
\hline VT.r & $v \leq .1$ & Vr.r & باب الشرقي & $r \varepsilon$ & VT.r & $v \cdot . r$ & VT.E & الدرويش & 10 \\
\hline$v 1.9$ & $v \cdot .1$ & VI. $\varepsilon$ & الحسينية & ro & vo.1 & $V \varepsilon . r$ & VY.r & المشتل/ القناة & 17 \\
\hline V^.r & Va.r & V^.r & الطالبية & ry & $v 0.9$ & Vr.T & Vo.r & مشتل/بلديات & iv \\
\hline 79.5 & VI.1 & VT.r & شارع فلسطين & $r v$ & Vฯ.r & จฯ.1 & V५.Y & ساحة ميسلون & 11 \\
\hline $77 . \varepsilon$ & 70.1 & $97 . r$ & باب المعظم & rA & V7.9 & V५.r & vo.r & ملعب الثعب & 19 \\
\hline \multirow{2}{*}{\multicolumn{5}{|c|}{ المصدر: عمل الباحث بالاعتماد على الرصد الميداني في العام ^ 1 ـ †. }} & $V \varepsilon . r$ & vo.r & Vo.r & باب المعظد & $r$ r. \\
\hline & & & & & 79.1 & $v \cdot . r$ & $v . .1$ & مدينة الطب & rI \\
\hline
\end{tabular}

ثانيا: التحليل المكاني والزماني للتلوث الضوضائي لأغلب مناطق عبور الجسور في جانب الرصافة في مدينة بغداد حسب استعمالات الأرض في شهر كانون الثاني:- 
المؤتمر العلمي الاولي الحادي عشر

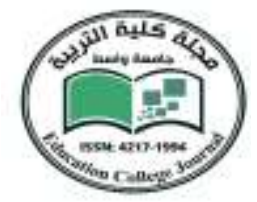

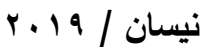

جامعة واسط

مجلــــة كليــــة التربيــــة

يتبين من الجدول (1) ان اعلى قياس للضوضاء في قاطع الرصافة بالنسبة لأغلب مناطق عبور

الجسور لمنطقة الدراسة كان في (السنك و المثنى)، اثناء رصد الضوضاء على بعد 0, متر من

موقع الجسر وبسبب الزحام المروري وبسبب وجود الكثير من الدوائر الرسمية والمناطق التجارية الرئيسية الموجودة في المناطق المذكورة انفا في الساعة التاسعة صباحا، خلال الرصدات الثلاثة خلال مدة الدراسة وكان اقل رصد للضوضاء في جهاز قياس الضوضاء بوحدة الديسبل من المناطق المختارة والمذكورة انفا، هي (جسر بغداد/الف دار و الصرافية)، ويعود ذلك الى سهولة الأنتقال خلال الجسور الأخيرة وأيضا بسبب محدودية استخدام الجسر الأول وسلاسة الانتقال خلال الجسر الثاني، والتحليل المذكور انفا ان مناطق عبور الجسور هي مناطق ملوثة ضوضائيا حسب المعيار العالمي • ثالثا: التحليل المكاني والزماني للتلوث الضوضائي لأغلب الاحياء الصناعية في جانب الرصافة في مدينة بغداد حسب استعمالات الأرض في شهر كانون الثاني:يتبين من الجدول (r) ان اغلب مناطق الاحياء الصناعية في قاطع الرصافة تعاني من تلوث ضوضائي وان هنالك تفاوت طفيف في الضوضاء بين منطقة وأخرى، ولكن على العدوم جميعها قيس بها ضوضاء غير مقبولة حسب المعايير العالمية والمحلية؛ حيث احتلت الترتيب الأول والثاني والثالث هي الاحياء الصناعية في (الطالبية و بغداد الجديدة و شيخ عمر)، ترتيبا تتازليا حتى رصد اقل ضوضاء في الرصدة الصباحية للعام 11 ب. في شهر كانون الثاني في الاحياء الصناعية لمنطقة (الحسينية) ويعود هذا التفاوت الى ان هنالك مناطق رئيسية كحي صناعي رئيسي وأخرى مناطق فرعية وثانوية توجد في اطراف بغداد اذا ما قيس الضوضاء بها بالمقارنة مع الأحياء الرئيسية.

رابعا: التحليل المكاني والزماني للتلوث الضوضائي لمداخل الجامعات والكليات في جانب الرصافة في مدينة بغداد حسب استعمالات الأرض في شهر كانون الثاني:يتبين من الجدول (ع) ان اعلى قياس للضوضاء للرصدة الصباحية في شهر كانون الثاني في الساعة التاسعة صباحا خلال الرصدات الثلاثة في جهاز قياس الضوضاء على بعد 1.0 متر ، حيث احتلت الترتيب الأول هي الجامعة المستصرية للتلوث الضوضائي، ويعود ذلك الى زحام دخول الطلبة وأيضا الزحام المروري لخطوط نقل الطلبة والموظفين بقرب بوابات دخول الجامعة، وأيضا بسبب موقع الجامعة بقرب من شارع رئيسي واساي في قاطع الرصافة، وقد احتل الترتيب الأخير في التلوث الضوضائي هي مدخل كلية الهندسة/الجامعة المستتصرية ويعود ذلك الى بعد مدخل الكلية 
المؤتمر العلمي الاولي الحادي عثر

عن الزحام المروري وأيضا الى غلق الثارع الرئيسي لها المقابل للكراج الموحد (باب المعظم) من قبل القوات الأمنية في قاطع الرصافة، وهذا له الدور الرئيسي في احتلالها الترتيب الأخير لقياس الضوضاء بجهاز الضوضاء على بعد r متر عن مدخل كلية الهندة، وعلى الرغم من التحليل

المذكور الأ انه ليس ضمن المعيار المسموح عالميا ومحليا.

\begin{tabular}{|c|c|c|c|c|c|c|c|c|c|}
\hline \multicolumn{5}{|c|}{ 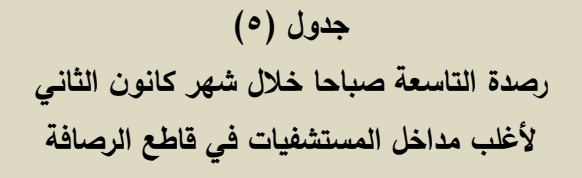 } & \multicolumn{5}{|c|}{ 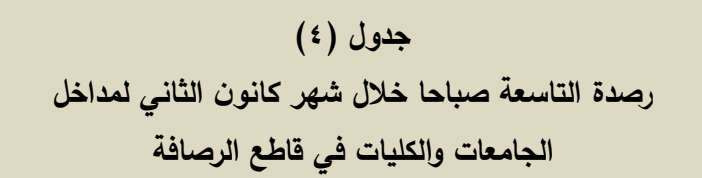 } \\
\hline 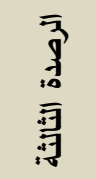 & 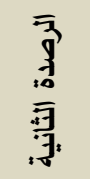 & \begin{tabular}{l}
$\overline{3}$ \\
\multicolumn{1}{c}{} \\
$\overline{3}$ \\
วิ
\end{tabular} & اسم الموقع & ت & 牙 & 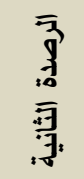 & $\begin{array}{l}\overline{3} \\
\overline{3} \\
\overline{3} \\
\overline{3}\end{array}$ & اسم الموقع & ت \\
\hline 70.8 & TV.r & ४ & مدينة & o. & VI. & $v \cdot . r$ & VY.l & مجمع باب المعظم & rq \\
\hline$v \cdot r r$ & VI.\& & $V \cdot . r$ & الشيخ زايد & 01 & $\neg \wedge . \varepsilon$ & $79 . r$ & $v \ldots \theta$ & كلية الهندسة & $\varepsilon$. \\
\hline$v 0.9$ & $V \varepsilon . \wedge$ & $V \leq . \varepsilon$ & الكندي & or & Vr.V & Vr. & $V \varepsilon . r$ & الفنون الجميلة & $\leqslant 1$ \\
\hline V.. 9 & V५.r & V५.r & لالعلوية & or & $V \leqslant .9$ & Vo.1 & Vo. & الجامعة المستنصرية & $\varepsilon r$ \\
\hline 71.9 & $79 . r$ & vi.v & ابن البيطار & 0 \& & Vo. 9 & $\vee \bullet . \wedge$ & Vr.s & الجامعة العراقية & $\varepsilon r$ \\
\hline 70.9 & 97.9 & 70.7 & ابن القفل الشبل & $\Delta 0$ & vi.r & $V \cdot . r$ & $v \ldots l$ & الإدارة واقتصاد بذاد & ؛ \\
\hline vo.r & Vr.r & V^.r & الزهراوي & 07 & vo.1 & VT.\& & VY.T & مستنصرية الإدارة اقتصاد & $\leqslant 0$ \\
\hline$\vee \bullet . \wedge$ & vo.r & Vr.s & ابن البلدي & ov & $\vee 4 . \wedge$ & $V \leq . r$ & vo.1 & الجامعة التكنلوجية & $\leqslant 7$ \\
\hline Tr. & $90 . \Gamma$ & & شهاب & $0 \wedge$ & $79 . \%$ & $v \cdot . \wedge$ & $v \ldots l$ & معهد تكنلوجيا زعفرانية & $\leqslant V$ \\
\hline \multirow{2}{*}{\multicolumn{5}{|c|}{ 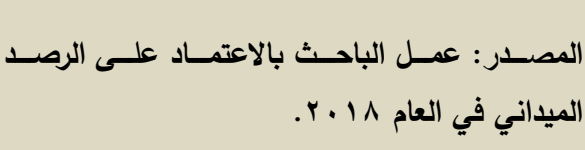 }} & vr.A & $V \leqslant . V$ & $v 0 . v$ & معهد الإدارة & $\varepsilon \wedge$ \\
\hline & & & & & $v \cdot . q$ & 79.4 & VI.\& & القانون/مستنصرية & $\leqslant 9$ \\
\hline
\end{tabular}


المؤتمر العلمي الاولي الحادي عشر

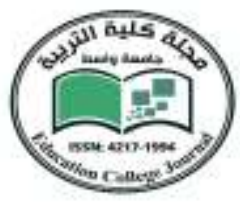

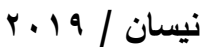

جامعة واسط

مجلــــة كليــــة التربيــــة

خامسا: التحليل المكاني والزماني للتلوث الضوضائي لأغلب مداخل المستثفيات في جانب الرصافة في مدينة بغداد حسب استعمالات الأرض في شهر كانون الثاني:-

يتبين من الجدول (0) ان اعلى قياس لمستويات الضوضاء في جانب الرصافة خلال العام

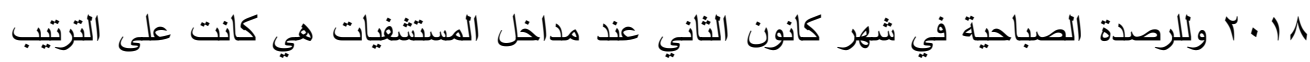
(مستثفى العلوية للولادة و مستثفى الزهراوي للولادة) ويعود ذلك الى طبيعة الحالات التي تعالجها

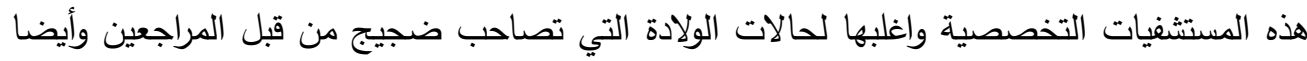

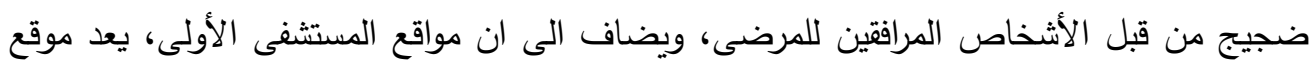

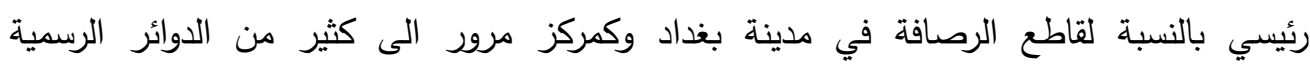

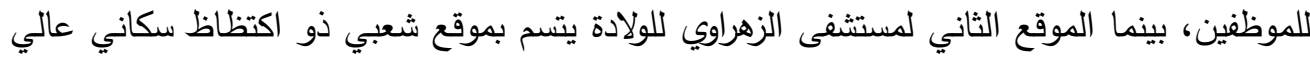

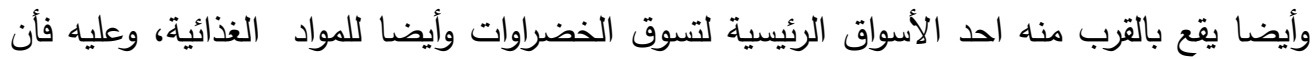
مستوى الضوضاء يكون جدا مرتفع وغير موافق للمعايير العالمية والمحلية.

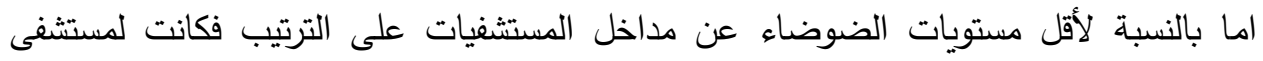

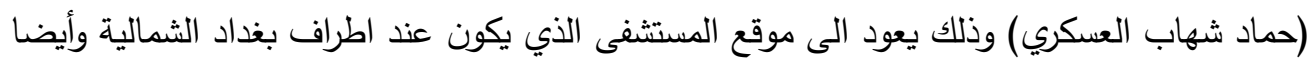

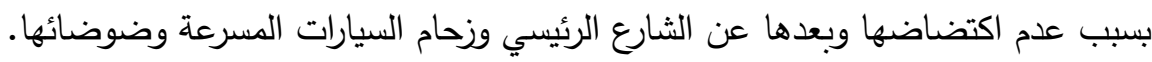

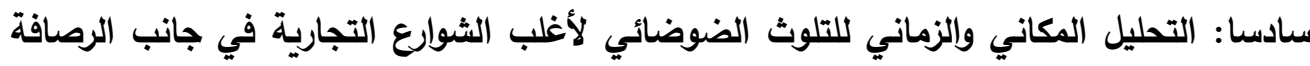
في مدينة بغداد حسب استعمالات الأرض في شهر كانون الثاني:-

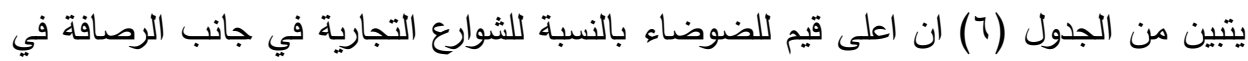

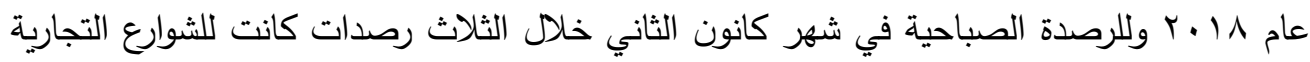

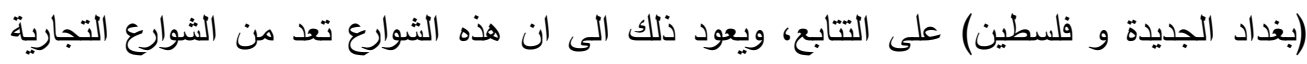

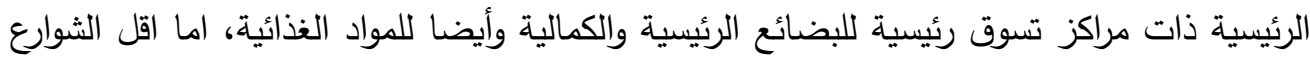

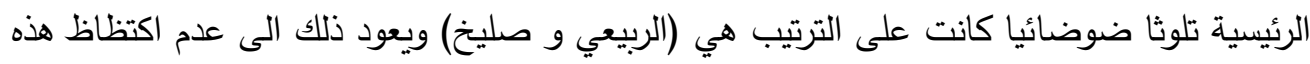

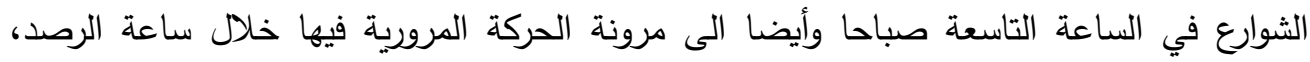
وعلى الرغم من ذلك فأن جميع الثوارع التجارية في جانب الرصافة ملوثة ضوضائيا حسب التبا المعايير

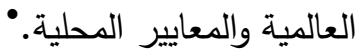


المؤتمر العلمي الدولي الحادي عثر

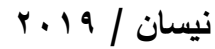

جامعة واسط

مجلــــة كليـــــة التربيــــة

\begin{tabular}{|c|c|c|c|c|c|c|c|c|c|}
\hline \multicolumn{5}{|c|}{ 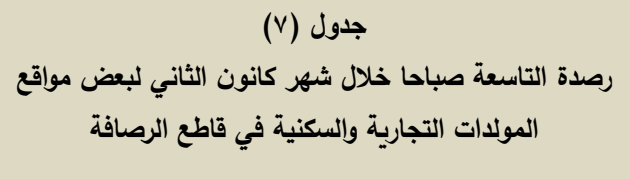 } & \multicolumn{5}{|c|}{ 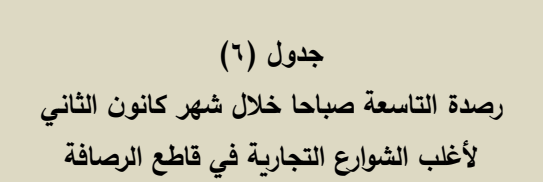 } \\
\hline 亨 & 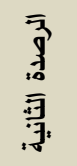 & 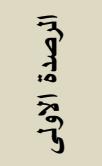 & اسم الموقع & $ت$ & 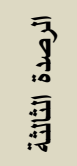 & 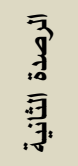 & 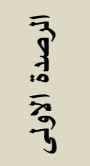 & اسم الموقع & ت \\
\hline 99.9 & $99 . \varepsilon$ & $1 \ldots \varepsilon$ & الشعب & 79 & V५.r & vo.r & $V \varepsilon . r$ & شارع & 09 \\
\hline 9 9.० & $9 \leqslant .9$ & 90.1 & صولدات & $v \cdot$ & VA. . & $\vee \wedge . \diamond$ & VA.r & فلسطين & 7. \\
\hline 19.0 & $91 . \varepsilon$ & $9 . .0$ & مولات بذاد & vi & $\Lambda . .1$ & V৭.० & VQ.r & 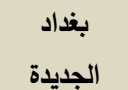 & 11 \\
\hline 1.1 .0 & 99.9 & १९.४ & مدينة الصدر & Vr & $V 7.9$ & $\vee 0 . \wedge$ & V५.r & شارع عدن & Tr \\
\hline 74.8 & 70.9 & 70.8 & مولدات & Vr & Vr. \& & $v \cdot .9$ & $v . .1$ & شكارع المكاتب & r \\
\hline$\vee \wedge . \wedge$ & VV.० & จ . & مولدات البلديات & $V \varepsilon$ & TV. \& & Ү & $79 . r$ & ش المطبك & $7 \varepsilon$ \\
\hline $9 . .9$ & $\wedge \wedge . \vee$ & 19.9 & مولدات & vo & 7ร.V & 74.9 & 70.8 & شارع الربيعي & 10 \\
\hline $0 \leqslant . \varepsilon$ & Or.\& & 01.7 & مولدات & VI & ד. & 74.9 & TY.A & شليخ & 74 \\
\hline$\varepsilon \varepsilon . r$ & $\leq 7.9$ & $\varepsilon r . r$ & الحسينية & VV & $V \leqslant .0$ & vo.0 & V५.r & ميسلون & IV \\
\hline \multicolumn{5}{|c|}{ 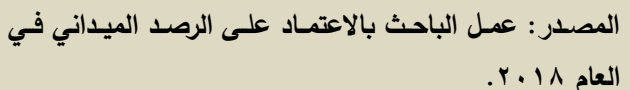 } & $V V . q$ & V५.० & VV.e & شارع كرادة & 71 \\
\hline
\end{tabular}


المؤتمر العلمي الاولي الحادي عشر

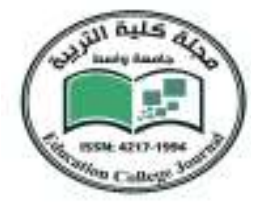

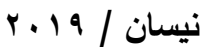

جامعة واسط

مجلــــة كليــــة التربيــــة

سابعا: التحليل المكاني والزماني للتلوث الضوضائي لبعض مواقع المولدات التجارية والسكنية في جانب الرصافة في مدينة بغداد حسب استعمالات الأرض في شهر كانون الثاني:يتبين من الجدول (V) ان اعلى معدل لقياس الضوضاء في جانب الرصافة في شهر كانون

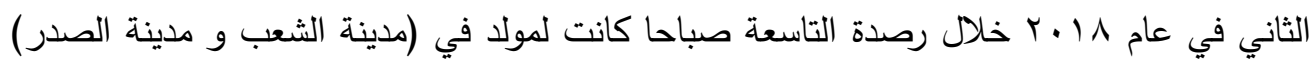
على الترتيب، ويعود ذلك الى زيادة العزم والطاقة المولدة من هذه المولدات بحكم موقعها التجاري

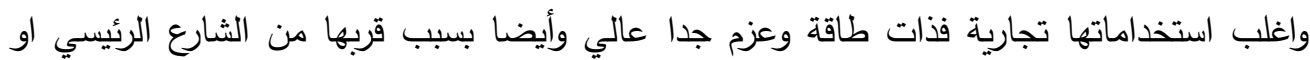

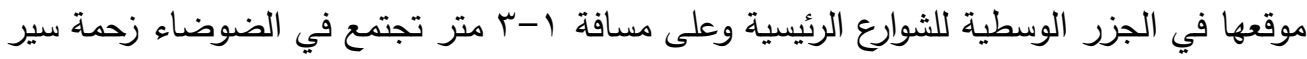

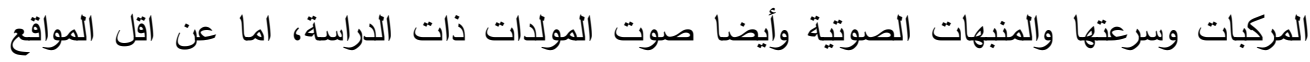
رصدا للضوضاء في المدينة كانت على التتابع موقع (منطقة الأمين و الحسينية)، كون هذه المناطق

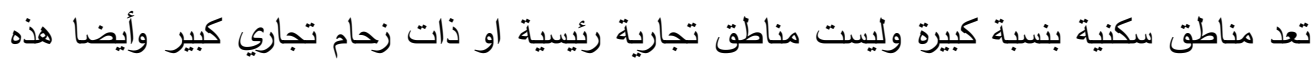
المولدات مولدات سكنية لا يوجب على صاحب المولد التثغيل الصباحي كونه موسم الثتاء الذي يتغاضى السكان عن حاجتهم للطاقة الكهربائية، وعلى الرغم من ذلك فهي غير مطابقة للمعايير العالمية والمحلية للضوضاء و كأستعمال سطح الأرض. •

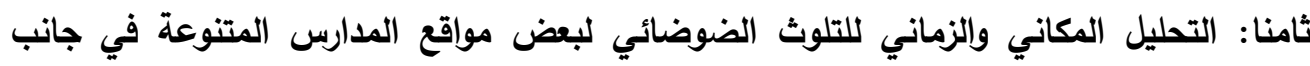
الرصافة في مدينة بذاد حسب استعمالات الأرض في شهر كانون الثاني:-

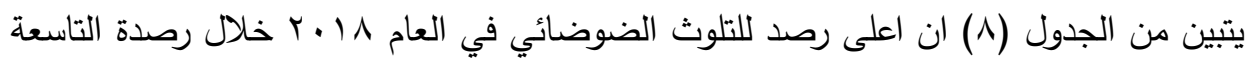

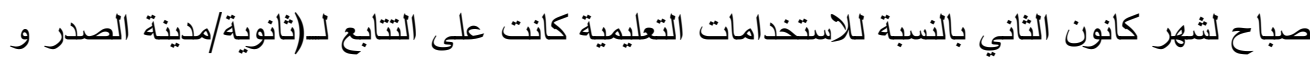

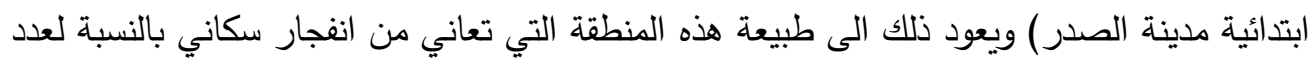

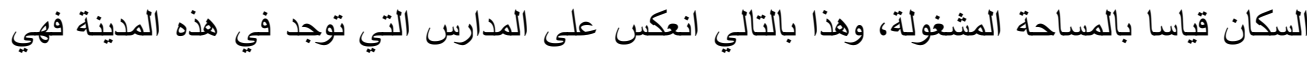

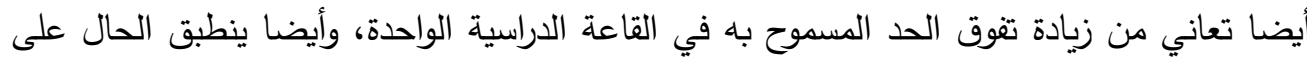
اغلب المدارس في المنطقة المذكورة انفا. اما اقل المدارس تلوثا ضوضائيا للرصدة ذاتها وللعام ذاته وفي الوقيت ذاته تنازليا وعلى الترتيب

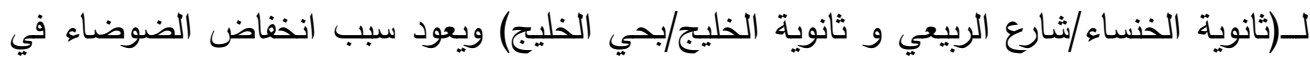

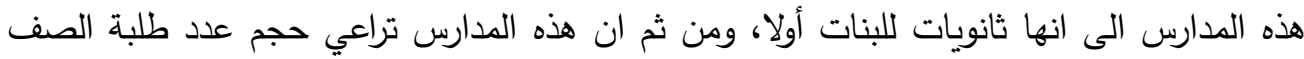

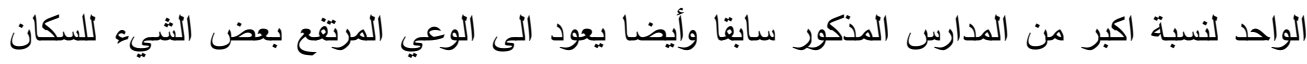

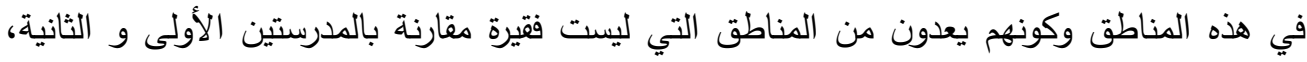


المؤتمر العلمي الدولي الحادي عشر

وان اغلب الضوضاء التي تم رصدها هي بسبب موقع المدارس الذي يكون بجوار شارع تجاري رئيسي في المنطقة المتواجدة فيها المدارس الأخيرة ويضاف لها ضجيج المدرسة، وعلى الرغم من ذلك فأن كل المدارس موضع الدراسة وخلال الرصد هي ليست مطابقة للمقاييس العالمية والمحلية

•لضوضاء.

\begin{tabular}{|c|c|c|c|c|c|c|c|c|c|}
\hline \multicolumn{5}{|c|}{ 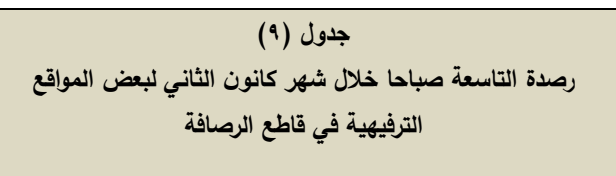 } & \multicolumn{5}{|c|}{ 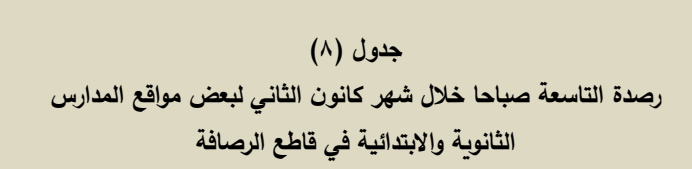 } \\
\hline 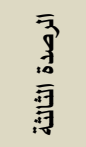 & 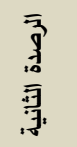 & 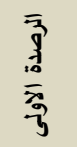 & 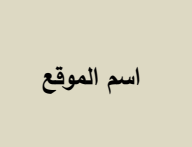 & $ت$ & 高 & 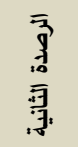 & 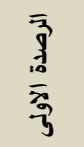 & 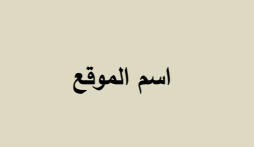 & $ت$ \\
\hline จฯ.V & V^.9 & V५.० & مدينة العاب السندباد & $\wedge \wedge$ & VV. & $v 0.0$ & vv.v & ث.المعالي/بغداد الجديدة & VA \\
\hline$v \leqslant .0$ & vo. & $v \varepsilon . r$ & مدينة العاب بغداد & $\wedge 9$ & vr.o & $V \varepsilon .0$ & vr.r & أ.الخليج/منطقة الدرويش & va \\
\hline$T \leqslant .1$ & 70.8 & $71 . r$ & الجزيرة السياحية & 9. & vr.t & Vr.o & Vr.o & ث.الخنساء شارع الربيعي & $\wedge$. \\
\hline 7.1 & 7.1 & 74.7 & حديقة بيت طبرة & 91 & $v \varepsilon . v$ & vr.9 & $v \varepsilon .0$ & ث.الاصمعي/الثعب & $\wedge 1$ \\
\hline$\varepsilon \cdot r$ & «1.r & $\varepsilon \ldots 1$ & كوفيات ومقاهي & ar & Vr. & $V \varepsilon . r$ & VY.r & م.طوعة/الحسينية & Ar \\
\hline$v \ldots l$ & 19.r & $\vartheta \Lambda . r$ & فلفراء شارع & 9 & VV.q & VA. 9 & VA.r & أ.السرور/الحسينية & AT \\
\hline D & O^.r & 00.1 & كورنيش إيليا & $9 \leq$ & V^.9 & $\vee \wedge . \diamond$ & VV.r & ث.المهندسين/المهندسين & $\wedge \varepsilon$ \\
\hline $0 \leqslant .0$ & OV.r & $09 . \%$ & ومقاهي متفرقة & 90 & $V \varepsilon . \wedge$ & Vr.q & vo.o & ث.صليخ/صليخ & 10 \\
\hline \multirow{2}{*}{\multicolumn{5}{|c|}{ 1ا المصدر: عـل الباحث بالاعتمـاد على الرصد الميداني في العام }} & V^.q & Va.० & va.9 & أبتائية/مدينة الصدر & 14 \\
\hline & & & & & $v 9.9$ & $\vee \wedge . \wedge$ & vV.q & ثانوية/مدينة الصدر & AV \\
\hline
\end{tabular}


المؤتمر العلمي الاولي الحادي عشر

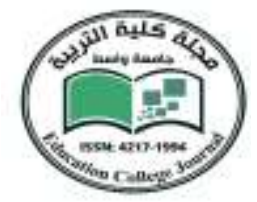

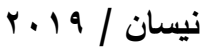

جامعة واسط

مجلــــة كليـــــة التربيــــة

تاسعا: التحليل المكاني والزماني للتلوث الضوضائي لبعض المواقع الترفيهية في جانب الرصافة في مدينة بغداد حسب استعمالات الأرض في شهر كانون الثاني:يتبين من الجدول (9) ان اعلى مستوى لرصد الضوضـاء خلال شهر كانون الثاني في الساعة

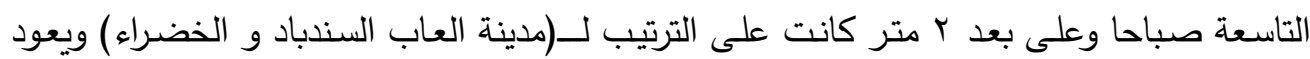
ذلك بالنسبة للأولى الى انها تعد مكان ترفيهي رئيسي واغلب سفرات طلبة المدارس تكون اليه وأيضا

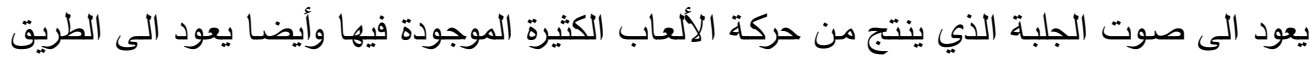

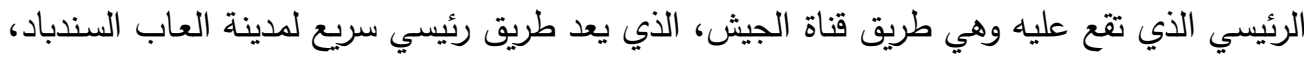

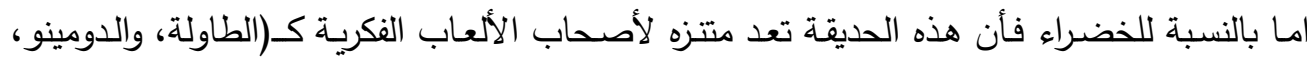

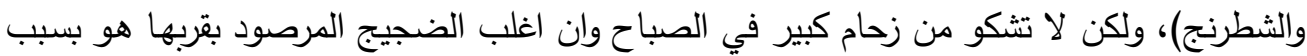

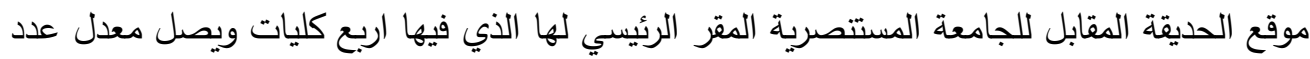

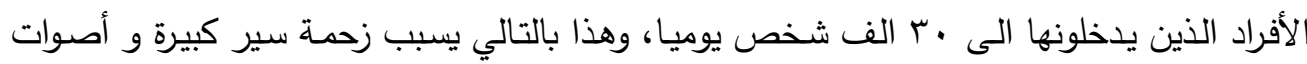

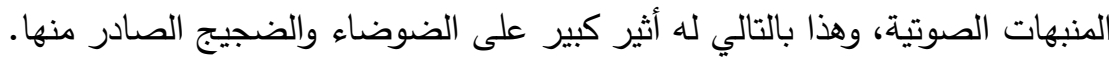
اما عن اقل ضوضساء تم رصده فكان للمواقع الترفيهية في (البنوك و كورنيش ومقاهي إئي إيليا في منطقة الكريعات) ويعود ذلك الى ان هذه المقاهي هي في الحقيقة مقاهي وكورنيشات ومواقع ترفيهية

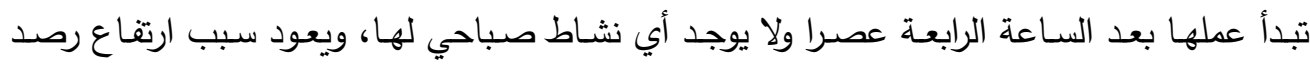

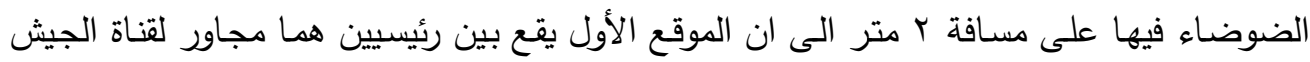

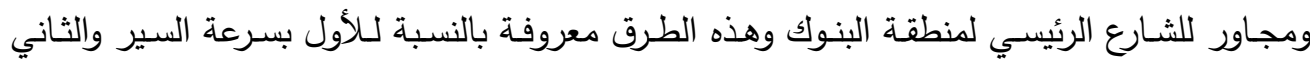
بالزحام الثديد وهذا ما سبب الضوضـاء اثثاء الرصد، وعليه يعد من ضمن المؤثرات على المناطق الترفيهية للضوضـاء، امـا الموقع الثاني هو بسبب وقوعها على المدخل الرئيسي لمنطقة الكريعات وضيق الطريق المؤدي لمدخل المنطقة فيعمل على احداث ضوضاء لماء بسبب عدم اتساع الطريق وكثرة

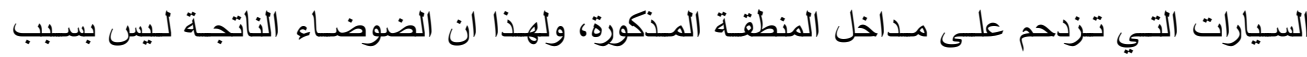

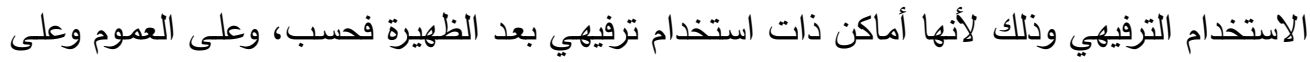
الرغم من الأسباب والتحليل الذي ذكر فأنها لا تلائم المعايير العالمية والمحلية للترفيه الا للموقعين الأخيرين المذكورين انفا. 
المؤتمر العلمي الاولي الحادي عشر

عاشرا: التحليل المكاني والزماني للتلوث الضوضائي لبعض مواقع التسوق المحلية في جانب الرصافة في مدينة بذاد حسب استعمالات الأرض في شهر كانون الثاني:-

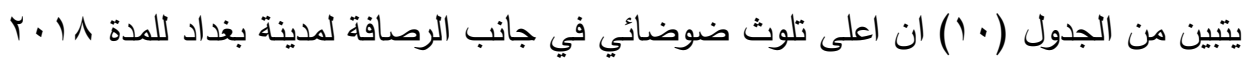

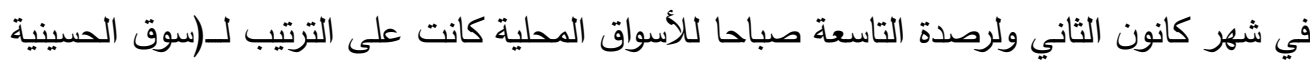

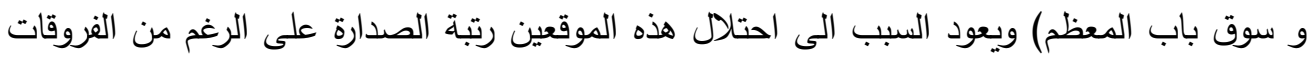

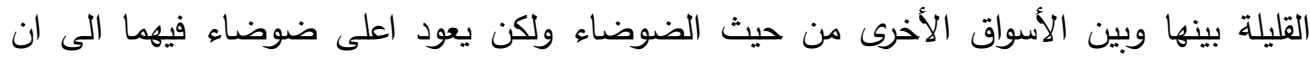

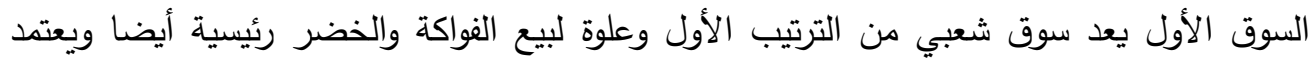

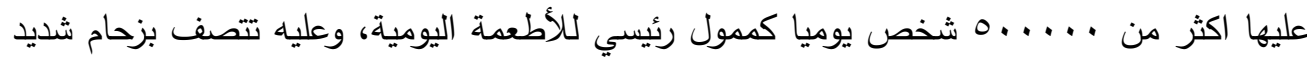

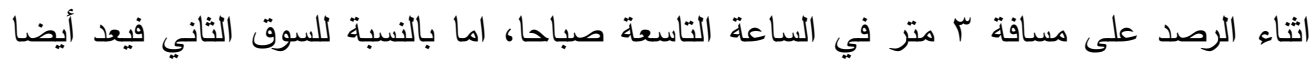

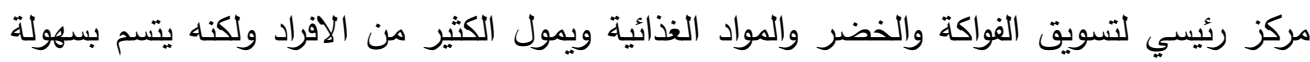

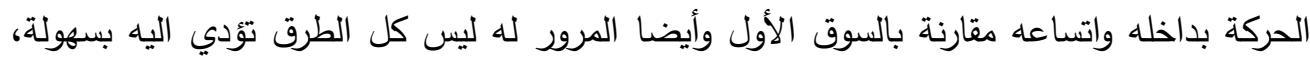

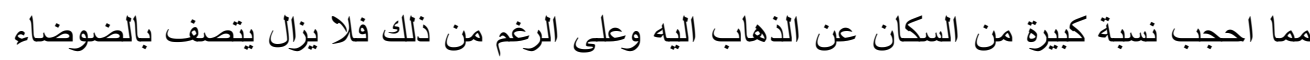

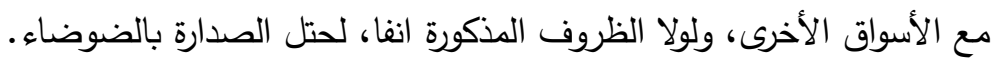
اما عن اقل الأسواق ضجيجا بين مناطق القياس المختارة كانت لسوق الفحامة، احتلالها الترتيب

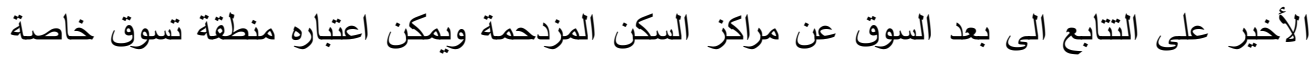

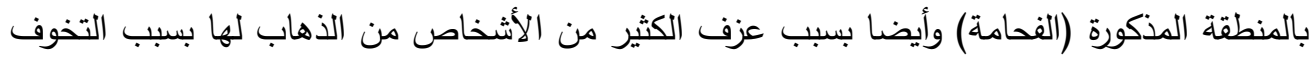

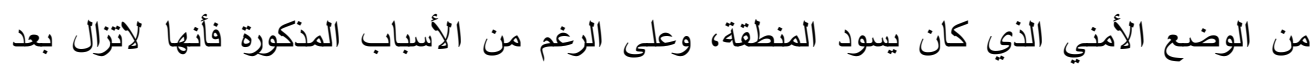
مطابقتها للمعايير العالمية والمحلية للضوضاء في مناطق الانود التسوق الدحلية. 
المؤتمر العلمي الدولي الحادي عثر

جدول (1.)

رصدة التاسعة صباحا خلال شهر كانون الثاني لبعض مواقع التسوق المحلية في قاطع الرصافة

\begin{tabular}{|c|c|c|c|c|}
\hline 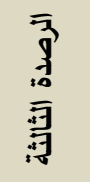 & 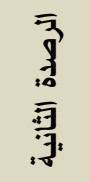 & 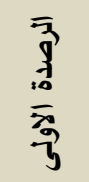 & اسم الموقع & ت \\
\hline ४1.० & 79.0 & $v \cdot .1$ & سوق الفحامة & 97 \\
\hline VI. & Vr.O & $v \leq .0$ & سوق الزراشدية & $9 \mathrm{~V}$ \\
\hline$v \leq . V$ & $\vee ५ . \wedge$ & VV.r & سوق ء الالاف & $9 \wedge$ \\
\hline$\vee \vee .1$ & $\vee \wedge . \diamond$ & VV.r & سوق بغداد الجديدة & 99 \\
\hline$\vee \wedge . \vee$ & v^.r & $\vee \wedge .9$ & سوق مدينة الصدر & $1 \ldots$ \\
\hline$\vee 7.9$ & $\vee \wedge .7$ & $\vee 9.1$ & سوق باب المعظم & 1.1 \\
\hline V १.v & Va.1 & A..r & سوق الحسينية & $1 \cdot r$ \\
\hline
\end{tabular}

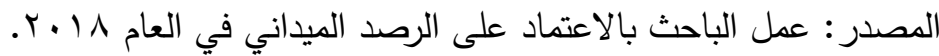

ب|/رصدة الساعة التاسعة مساءا لقياس التلوث الضوضائي في جانب الرصافة لمدينة بغداد في

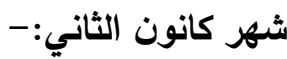
أولا: التحليل المكاني والزماني للتلوث الضوضائي لأغلب تقاطعات الطرق في جانب الرصافة في مدينة بغداد حسب استعمالات الأرض في شهر كانون الثاني:يتبين من الجدول (1) ان اعلى مستوى للضوضـاء للتقاطعات المروريـة في جانب الرصافة في مدينة بغداد خلال الرصدة الليلية في شهر كانون الثاني للعام ^ 1 ـ ب وبثلاث رصدات لكل موقع في الثهر المذكور ان اعلى مستوى للضوضاء كان لموقعي (ساحة ميسلون وساحة بيروت) على التتابع ويعود ذلك الى هذه المناطق تعد منـاطق للتـزه الليلي في عموم قاطع الرصـافة لكثير من العوائل القاطنة بالقرب من هذه المناطق وحتى البعيدة عنها يلجؤن اليها لأجل التتزه وأيضا من اجل التجوال وهذا يسبب زحمة في السير واختناقات مروريـة تجلب الضوضـاء الى هذه المناطق اثناء الرصد، امـا بالنسبة عن اقل المواقع (التقاطعات المروريـة) تلوثا ضوضـائيا كانت على الترتيب (مدينـة الطب و مطعم الامير) ويعود ذلك الى منـع الزيارة الليلية للمرضـى في المستشفى الرئيسية فـلا يوجد زخم للمراجعين على هذا التقاطع وانتهاء الدوام الرسـمي والفعلي فـلا يوجد زحام للموظفين وانمـا مجرد الموظفين المخفرين ليلا وهؤلاء لايكون وجودهم يسبب ضجيجا، اما بالنسبة لمطعم الأمير فهي منطقة 
المؤتمر العلمي الاولي الحادي عثر

نيسان / 19

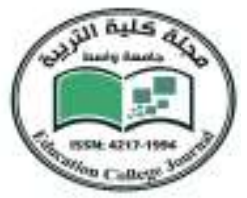

\section{جامعة واسط}

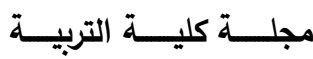

سكنية بحتة لا يوجد بها أي نشاط صناعي والحركة التجارية فيها تكون قليلة جدا في الساعة التاسعة ليلا اثناء الرصد والضوضاء التي توجد فيها فقط بسبب حركة السير، وعلى هذا فهي ليست مطابقة للمعايير العالمية

والمحلية بالنسبة للتقاطع الأخير ومقبولة وجيدة وبالنسبة لمدينة الطب للضوضاء في هذه الأماكن ليلا.

\begin{tabular}{|c|c|c|c|c|c|c|c|c|c|}
\hline \multicolumn{5}{|c|}{ 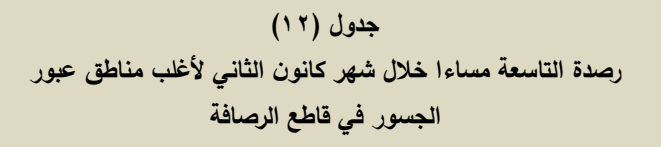 } & \multicolumn{5}{|c|}{ رصدة التاسعة مساءا خلال شهر كانون الثاني لأغلب تقاطعات الطرق } \\
\hline 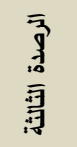 & 亨 & $\begin{array}{l}\overline{3} \\
\overline{1} \\
\overline{10} \\
3 \\
3\end{array}$ & اسم الموقع & $ت$ & 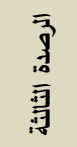 & 亨 & 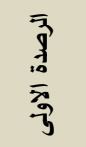 & اسم الموقع & $ت$ \\
\hline 9 Ir.o & Tr.\& & $T r . r$ & المثنى & rr & Tr.r & 10.1 & $10 . r$ & مطعم الامير & 1 \\
\hline 71.9 & 79.1 & 79.7 & الصرافية & $r r$ & vi.r & $v \cdot .0$ & vi.1 & شارع الصحة & $r$ \\
\hline Ir.o & $T . r$ & $T r . r$ & باب المطظم & $r \varepsilon$ & $v 1.9$ & VY.Y & vr.o & جامع النداء & $r$ \\
\hline TV.0 & 71.1 & TV.V & السنك & ro & $v \leq .1$ & $v \leqslant .0$ & $v \leqslant .1$ & تقاطع الموال & $\varepsilon$ \\
\hline VY.r & vi.r & VI.r & صليخ & $r q$ & $V \leqslant .9$ & $v 0 . r$ & $v_{0.1}$ & ساحة بيروت & 0 \\
\hline TV.V & 71.9 & $7 \wedge . \wedge$ & بغداد الف دار & $r v$ & vr.q & $\mathrm{vr} .9$ & $v \leqslant .1$ & مول النخيل & 1 \\
\hline$V \varepsilon .1$ & $\mathrm{v} 0.1$ & $V \varepsilon . \varepsilon$ & ابونؤاس/المنصور & rA & $79 . r$ & $79 . r$ & 79.1 & الباب الثرقي & $v$ \\
\hline$v \varepsilon . \wedge$ & vo.1 & $v \varepsilon .1$ & الثعب & rq & 79.4 & 71.1 & YA.Y & باب المعظم & $\wedge$ \\
\hline VY.r & vi.r & v1.1 & البنوك/الوزيرية & $r$. & 10.8 & $90 . r$ & 10.1 & تقاطع النهضة & 9 \\
\hline \multirow{2}{*}{\multicolumn{5}{|c|}{ رصدة التاسعة مساءا خلال شهر كانون الثاني لأغلب الأحياء الصناعية }} & VY.O & VY.\& & VY.r & سوق الحي & 1. \\
\hline & & & & & $v \cdot . r$ & $v \ldots \varepsilon$ & $v \ldots o$ & المهندسين & 11 \\
\hline 亨 & 离 & $\begin{array}{c}\overline{3} \\
\text { s. } \\
\overline{10} \\
\overline{3}\end{array}$ & اسم الموقع & $ت$ & $v \cdots . q$ & $v \cdot .0$ & $r . . r$ & الخلاني & Ir \\
\hline$\varepsilon v . r$ & $\varepsilon \wedge .0$ & $\leq 0 . r$ & بغداد الجديدة & $r_{1}$ & 79.4 & vi.r & vi.e & ساحة الوثبة & ir \\
\hline$\leqslant \vee .9$ & $\leqslant \wedge . \bullet$ & $\leqslant \wedge .9$ & شيخ عمر & rr & VI. & $v \cdot . \varepsilon$ & $V \ldots r$ & سينما البيضاء & $1 \varepsilon$ \\
\hline or.1 & or.o & or.r. & باب الشرقي & $r \varepsilon$ & VT.O & $v r . \xi$ & VT.r & الارويش & 10 \\
\hline $0 \wedge . \varepsilon$ & ०१.r & OA.r & الحسينية & ro & Vr.I & vi.1 & $v_{1.0}$ & المشتل مع القناة & 17 \\
\hline 10.0 & $1 \leq .0$ & Tr.r & الطالبية & $m q$ & 79.9 & VY.r & vi.0 & مشتل مع بلديات & iv \\
\hline 74.1 & IV.e & $74 . r$ & شارع فلسطين & $r v$ & V.. & $V \leq .9$ & vV.r & ساحة ميسلون & 11 \\
\hline 10.9 & $90 . r$ & 90.0 & باب المعظم & $\mu \wedge$ & $v \leq .1$ & $v r .9$ & $\mathrm{Vr} .1$ & ملعب الثعب & 19 \\
\hline \multirow{2}{*}{\multicolumn{5}{|c|}{ 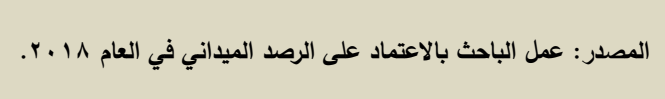 }} & $7 \leqslant .1$ & $90 . r$ & $7 \leqslant . \varepsilon$ & باب المغظم بفلسطين & $r$. \\
\hline & & & & & $0 V .9$ & OA.r & $0 \wedge .1$ & مدينة الطب & rI \\
\hline
\end{tabular}


المؤتمر العلمي الاولي الحادي عشر

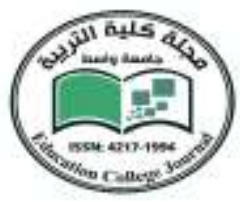

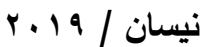

جامعة واسط

مجلــــة كليـــــة التربيــــة

ثانيا: التحليل المكاني والزماني للتلوث الضوضائي لأغلب مناطق عبور الجسور في جانب الرصافة في مدينة بذاد حسب استعمالات الأرض في شهر كانون الثاني:-

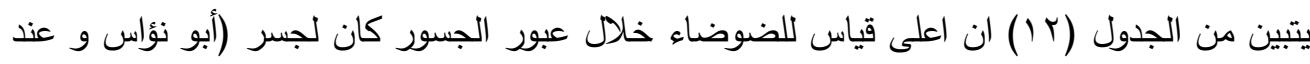
جسر الشعب) ويعود ذلك بالنسبة للأول لأنه يعد مناطق للتوجه الى مناطق تجارية رئيسية في مدئ مدينة

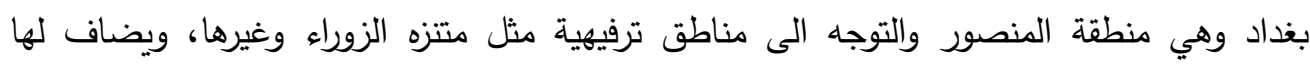

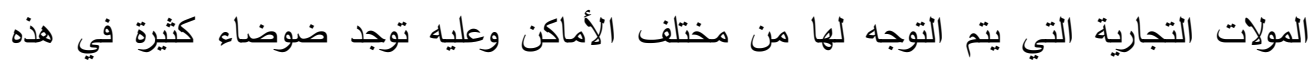

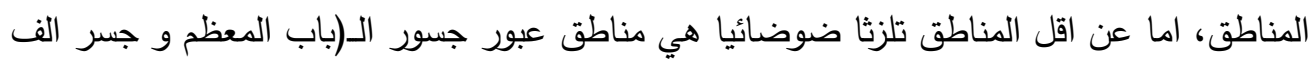

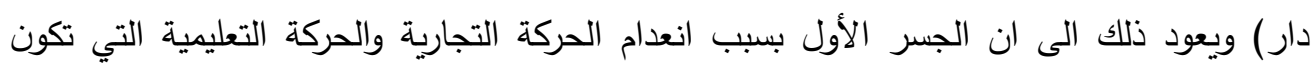

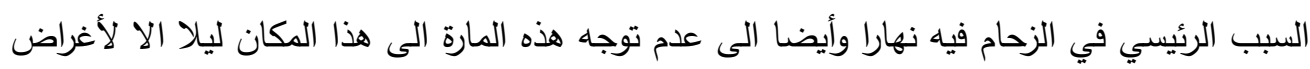

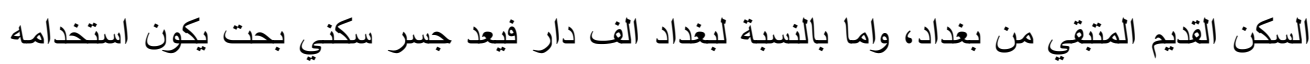

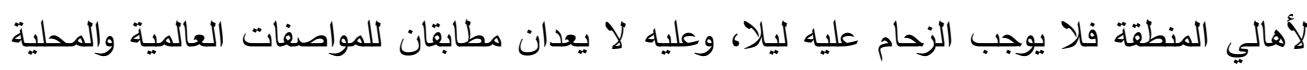
للضوضاء.

ثالثا: التحليل المكاني والزماني للتلوث الضوضائي لأغلب مناطق عبور الجسور في جانب الرصافة في مدينة بغداد حسب استعمالات الأرض في شهر كانون الثاني:-

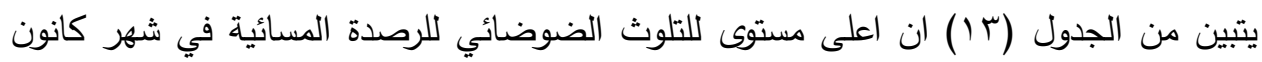

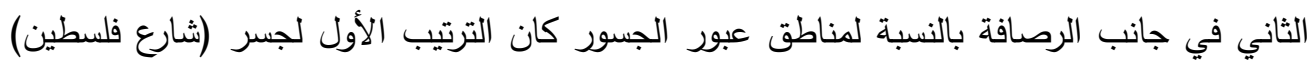

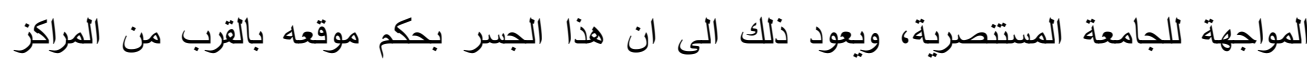

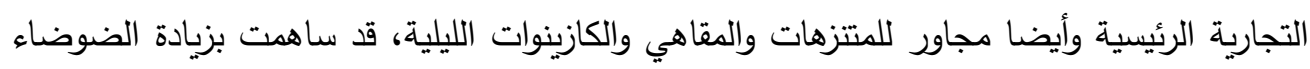

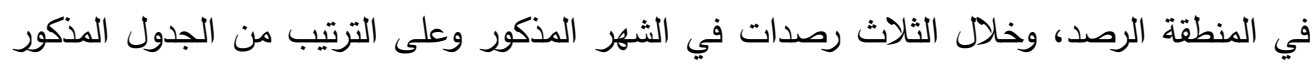

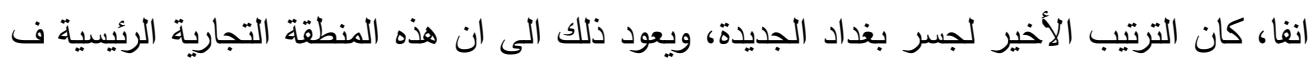

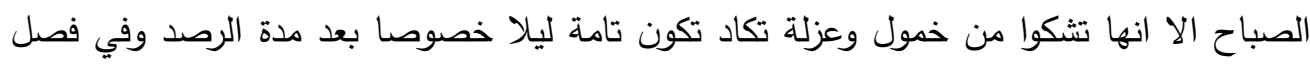

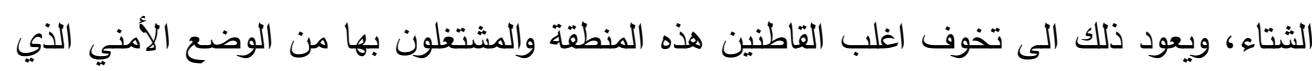

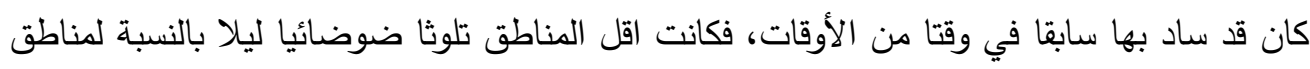

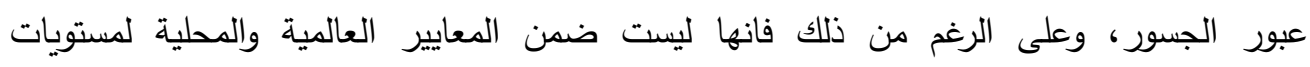
الضوضاء المقبولة بالنسبة للمنطقة الأولى وهي ضمن المعيار المسموح به للمنطقة الأخير (بغداد • الجديدة). 
المؤتمر العلمي الاولي الحادي عثر

ن بيسان / 19

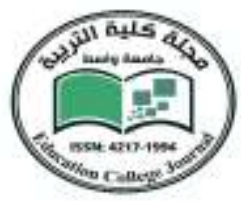

\section{جامعة واسط}

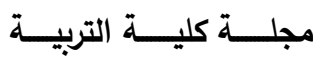

رابعا: التحليل المكاني والزماني للتلوث الضوضائي لمداخل الجامعات وإلكليات في جانب الرصافة في مدينة بغداد حسب استعمالات الأرض في شهر كانون الثاني:-

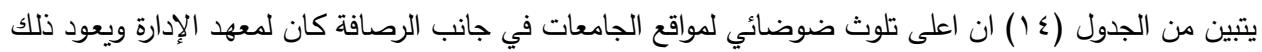

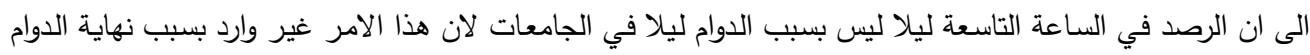

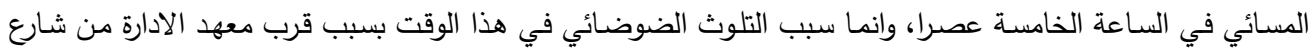

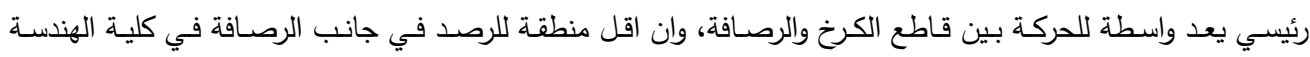

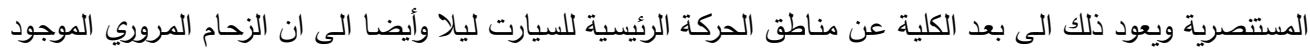

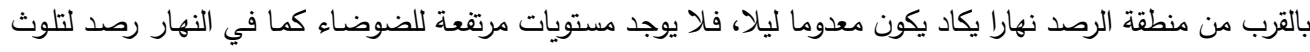

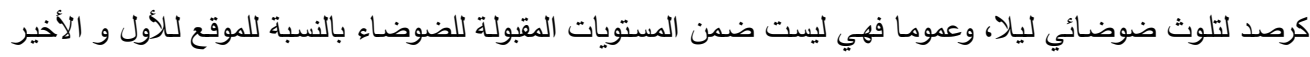

وليست ضمن المستويات المقبولة للضوضاء للمعيار العالمي.

\begin{tabular}{|c|c|c|c|c|c|c|c|c|c|}
\hline \multicolumn{5}{|c|}{ 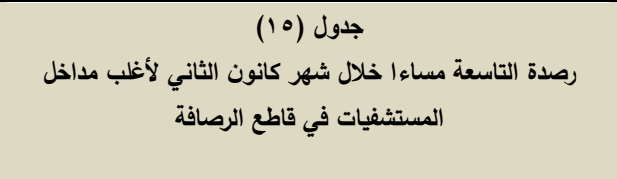 } & \multicolumn{5}{|c|}{ رصدة التاسعة مساءا خلال شهر كانون الثاني لدداخل الجامعات والكليات } \\
\hline 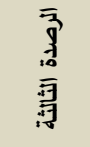 & 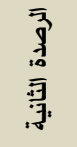 & $\begin{array}{l}\overline{3} \\
\overline{1} \\
\overline{3} \\
\overline{3}\end{array}$ & اسم الموقع & 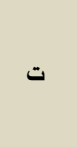 & 亦 & 勇 & 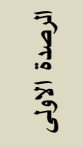 & اسم الموقع & $ت$ \\
\hline $71 . r$ & $\pi . r$ & 71.1 & مدينة الطب & o. & $0 \leq . T$ & $0 . \Gamma$ & OV.r & مجمع باب المعظم & rq \\
\hline TV.A & TV.A & TV.r & الثيخ زايد & 01 & or.9 & Or.A & or.r & كلية الهندسة مستنصرية & $\varepsilon$ \\
\hline 17.9 & TV.r & Tร. & الكندي & or & $7 \varepsilon .1$ & $1 \leq .1$ & Tr.r & الفنون الجميلة & \& \\
\hline १ง.r & १^.r & 71.1 & ل العلوية & or & 74. & iv.e & 90.0 & الجامعة المستصرية & $\varepsilon r$ \\
\hline Ir.q & 94.9 & $94 . \wedge$ & ابن البيطار & $0 \leqslant$ & 09.7 & Oq.r & 09.1 & الجامعة العراقية & $\varepsilon$ \\
\hline 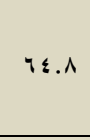 & 90.4 & $7 \leqslant .1$ & ابن القفل & $\infty$ & 04. & OV.r & $0 . .1$ & الإدارة واقتصاد بغاد & ؛ \\
\hline in.r & IV.r & $71 . r$ & الزهراوي & 04 & OV.A & $0 \wedge .1$ & OV.r & الإدارة اقتصاد مستنصرية & $\leqslant 0$ \\
\hline 10.1 & 10.0 & $70 . r$ & ابن البلاي & ov & $7 \varepsilon .1$ & 90.8 & $T \varepsilon . Y$ & الجامعة التكنلوجية & $\leqslant 4$ \\
\hline Or.r & $0 . r$ & $01 . r$ & حماد شهاب & $0 \wedge$ & $0 \wedge .9$ & O^.r & $0 \wedge .1$ & معهد تكنلوجيا زعفرانية & $\varepsilon v$ \\
\hline \multirow{2}{*}{\multicolumn{5}{|c|}{ 1ا المصدر. : عـل الباحث بالاعتمـاد على الرصد الميداني في العام }} & $v . .0$ & $v \cdot . r$ & $v 1.1$ & معهة الإدارة & $\varepsilon \wedge$ \\
\hline & & & & & OV.r & 07.0 & $04 . \%$ & القانون/مستنصرية & $\varepsilon 9$ \\
\hline
\end{tabular}


المؤتمر العلمي الاولي الحادي عشر

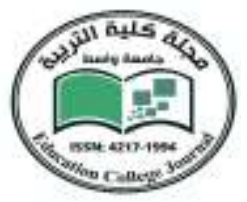

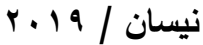

جامعة واسط

مجلــــة كليــــة التربيــــة

خامسا: التحليل المكاني والزماني للتلوث الضوضائي لأغلب مداخل المستثفيات في جانب الرصافة في مدينة بغداد حسب استعمالات الأرض في شهر كانون الثاني:-

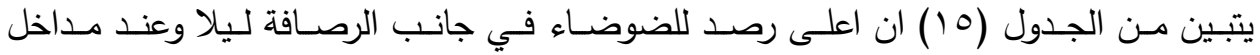

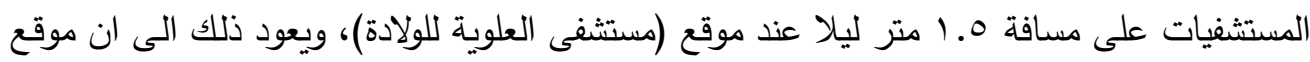
المستثفى يعد موقع مركزي لحالات الولادات في القطاع الحكومي وتتصف بزحام للمراجعين ليلا ونهارا واضافة الى الحالات الطارئة التي تصل اليها ليلا، وعلى الترتيب حتى عن اقل المستثفيات

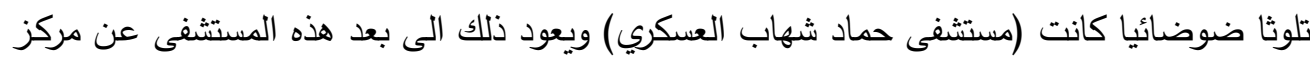

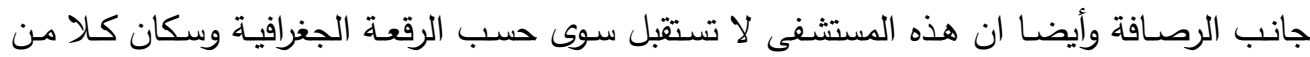

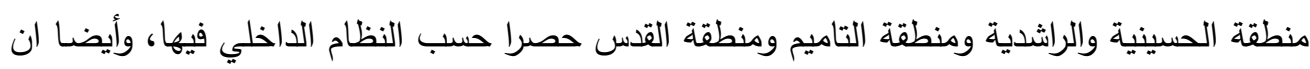

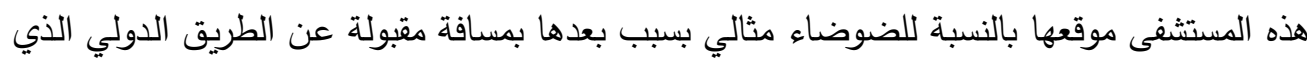

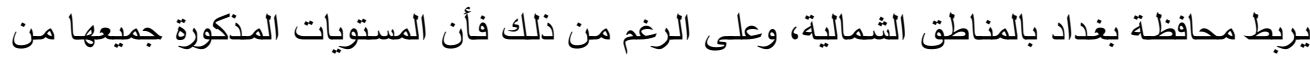
اعلى رصد الى اقل رصد ليست ضمن المعايير المقبولة للضوضاء عالميا ومحليا.

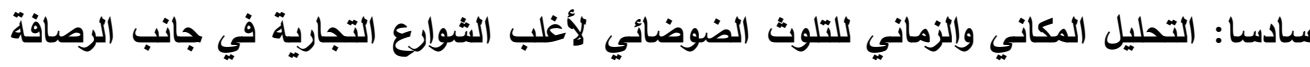
في مدينة بغداد حسب استعمالات الأرض في شهر كانون الثاني:يتبين من الجدول (7 (1) ان اعلى رصد للضوضاء للشوارع التجارية الرئيسية في جانب الرصافة

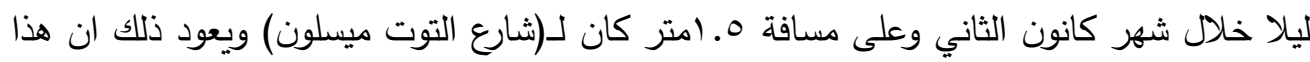

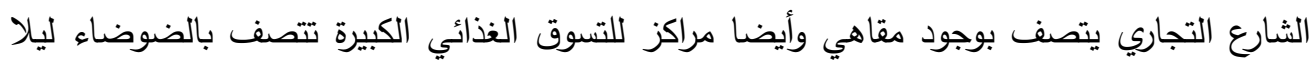

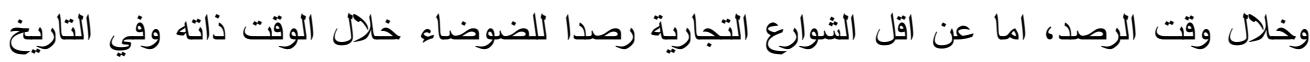
ذاته كان لشارع (المكاتب) وذلك لان هذا الثارع يتصف بالركود التجاري ليلا فلا يوجد به ضوضلاء التهاء التهاء

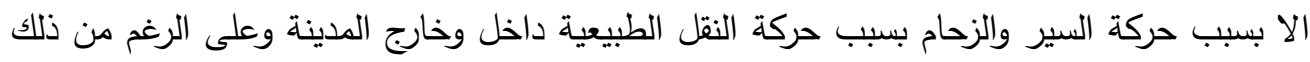
فأنها لا تقع ضمن المحددات المقبولة عالميا ومحليا. 
المؤتمر العلمي الدولي الحادي عشر

\begin{tabular}{|c|c|c|c|c|c|c|c|c|c|}
\hline \multicolumn{5}{|c|}{ 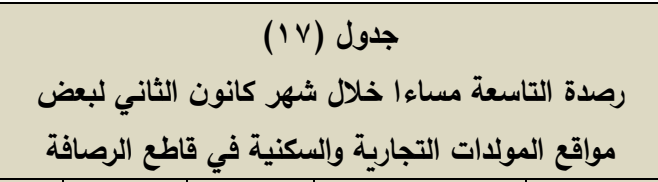 } & \multicolumn{5}{|c|}{ 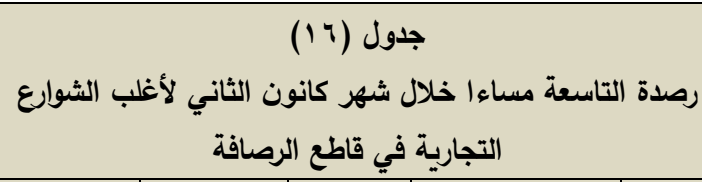 } \\
\hline ד্য় & 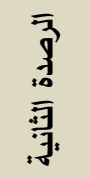 & $\begin{array}{l}\overline{3} \\
\overline{3} \\
\overline{3} \\
\bar{\jmath}\end{array}$ & اسم الموقع & ت & 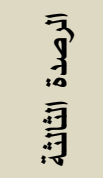 & 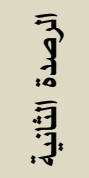 & $\begin{array}{l}\overline{3} \\
\bar{s} \\
\overline{3} \\
\bar{\jmath}\end{array}$ & اسم الموقع & ت \\
\hline $\begin{array}{l}94 \\
\text { q }\end{array}$ & q५.० & ar.r & الثعب & 79 & 79.4 & $\curlyvee \wedge . \wedge$ & Ү & شارع البنوك & 09 \\
\hline $\begin{array}{l}94 \\
.9\end{array}$ & ar.r & 91.r & مولدات صليخ & $v$. & 90.1 & $7 \leqslant .0$ & Tr.o & شارع فلسطين & 9. \\
\hline $\begin{array}{l}94 \\
.7\end{array}$ & 91.0 & $9 \leq . r$ & مولدات بغداد & vi & ษ . & $1 \wedge .1$ & TV.r & بغداد الجديدة & 91 \\
\hline $\begin{array}{l}97 \\
.8\end{array}$ & 90.0 & $90 . r$ & مولدات مدينة & Vr & $\because 1.0$ & ૧人.r & ૧ヘ.r & شارع عدن & Tr \\
\hline $\begin{array}{l}9 \leq \\
.1\end{array}$ & qr.r & qr.r & المشتلدات & $v r$ & 70.9 & To.r & 70.1 & شارع المكاتب & זי \\
\hline $\begin{array}{l}94 \\
.1\end{array}$ & $q \leq . r$ & $9 \leq .1$ & مولدات البلديات & $V \leq$ & IV.1 & IV.V & TV.r & شارع المطبك & $9 \varepsilon$ \\
\hline $\begin{array}{l}94 \\
.9\end{array}$ & $91 . r$ & $91 . r$ & مولدات القاهرة & vo & $v \cdot .9$ & vi.r & $v 1.1$ & شارع الزبيعي & 90 \\
\hline $\begin{array}{l}94 \\
.9\end{array}$ & qr.r & qr.r & مولدات الأمين & Vq & $7 \leq .0$ & T 1.0 & $T \leq . T$ & شارع صليخ & 97 \\
\hline $\begin{array}{l}\wedge 9 \\
. r\end{array}$ & $9 . .7$ & $9 . . \varepsilon$ & الحسينية & $v V$ & Vr.o & VY.r & Vr.r & شارع التوت & IV \\
\hline & & على & ل الباحث بالا: & العصد & vi.e & $v \cdot .0$ & ૧ . & شارع كرادة & $7 \wedge$ \\
\hline
\end{tabular}


المؤتمر العلمي الاولي الحادي عثر

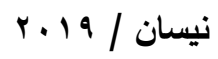

جامعة واسط

مجلــــة كليــــة التربيــــة

سابعا: التحليل المكاني والزماني للتلوث الضوضائي لبعض مواقع المولدات التجارية والسكنية في جانب الرصافة في مدينة بغداد حسب استعمالات الأرض في شهر كانون الثاني:يتبين من الجدول (IV) ان اعلى رصد للضوضاء خلال شهر كانون الثاني للرصدة المسائية في جانب الرصافة كانت لمولدات (مدينة الصدر) قد احتلت الترتيب الأول من حيث التلوث الضوضائي (السمعي) خلال الرصدات الثلاثة، وعلى الترتيب حتى الوصول الى الترتيب الأخير كانت لمولدات منطقة (القاهرة) ويعود ذلك الى ان هذه المنطقة تختلف المنطقة الأولى في ان الكثافة السكانية اقل من المنطقة الأولى ويضـاف لها زيـادة الحمل والطاقة المولدات الموجود في مدينة الصدر قياسـا بالمنطقـة الأخير وعلى العمـوم هـي مخالفـة للمعـيير الدوليـة والمحليـة ضــن المستويات المقبولــة للضوضاء بالنسبة للمكائن والمعدات الأخرى ذات الطاقة. ثامنا: التحليل المكاني والزماني للتلوث الضوضائي لبعض مواقع المدارس المتنوعة في جانب الرصافة في مدينة بغداد حسب استعمالات الأرض في شهر كانون الثاني:-

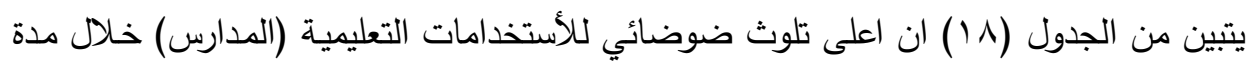
الدراسة وللرصدة الليلية كان الترتيب الأول لمدارس ثانوية في مدينة الصدر على بعد مسافة هـ امتر ويعود ذلك التلوث الضوضائي ليس الى الدوام الرسمي في الرصدة الليلية، لان هذا الامر غير وارد بتاتا وانما يعود ذلك الى ان هذه المدينة بشكل عام تتصف بزيـادة سكانية عالية جدا اذا ما قورنت بياقي مدن جانب الرصافة، وعلى الترتيب حتى اقل تلوث ضوضائي في مدرسـة (السرور ) في مدينة الحسينية وهذا الانخفاض في التلوث الضوضـائي في هذا السـاعة المسائية الى قلـة السكان او قلـة الاستخدامات البشرية المختلفة، وانمـا يعود ذلك الى موقع المدرسـة المذكور الذي يقع بين الاحياء السكنية وعلى الاغلب تتوسط الحي السكني وبعيدة عن الشوارع الرئيسية، وعلى الرغم من ذلك فان

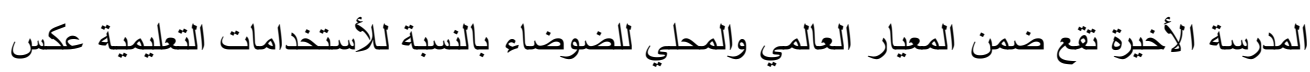

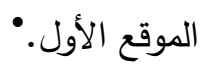

تاسعا: التحليل المكاني والزماني للتلوث الضوضائي لبعض المواقع الترفيهية في جانب الرصافة في مدينة بغداد حسب استعمالات الأرض في شهر كانون الثاني:-

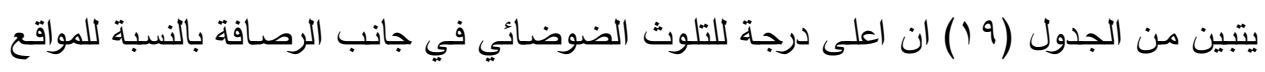
الترفيهية في الرصدة المسـائية كانت لحدائق ومقاهي (الخضـراء في شـارع فلسطين) الترتيب الأول

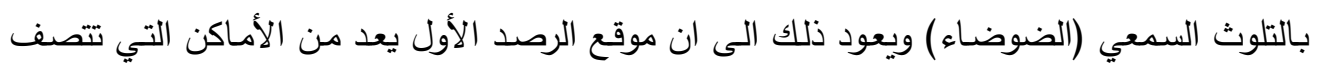

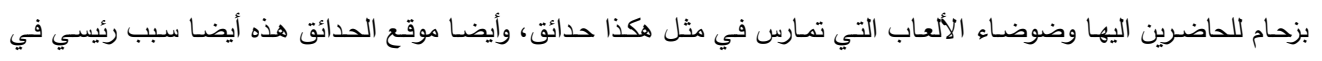


المؤتمر العلمي الاولي الحادي عثر

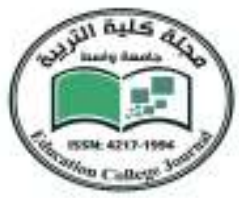

ن بيسان / 19

جامعة واسط

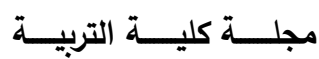

الضوضاء وذلك لوقوعها على شارع رئيسي ومركزي للأنتقال بين الرصافة والكرخ، اما بالنسبة لأقل المواقع الترفيهية تلوثا ضوضائيا

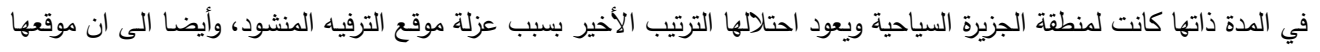

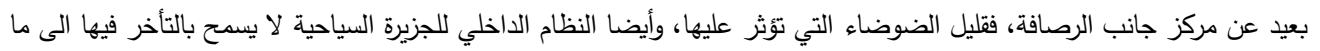

بعد الساعة العاشرة مساءا وعلى الرغم من ذلك فأن كل المواقع لا تطابق المعايير العالمية والمحلية للضوضاء والصحة.

\begin{tabular}{|c|c|c|c|c|c|c|c|c|c|}
\hline \multicolumn{5}{|c|}{ 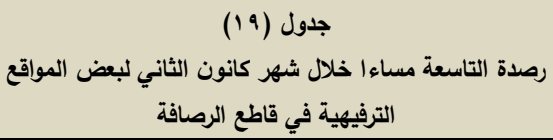 } & \multicolumn{5}{|c|}{ رصدة التاسعة مساء خلال شهر كانون الثاني لبعض مواقع المدارس الثانوية } \\
\hline الثاثثة & الثرانية & 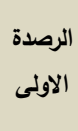 & اسم الموقع & $ت$ & 亨 & 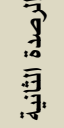 & 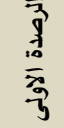 & اسم الموقع & $ت$ \\
\hline 79.9 & $v \ldots l$ & $79 . \%$ & العنداب & $\wedge \wedge$ & rᄉ.\& & rV. & r N.r & ث.المعالي/بغداد الجديدة & $\mathrm{VA}$ \\
\hline vi.r & VY.I & VI.r & العاب بذداد & $\wedge 9$ & rv.v & r.. & ro.o & أ.الخليج/منطقة الدرويش & va \\
\hline $0 . r$ & 0.99 & 01.0 & السياحية & 9. & ra.v & ra.1 & ra.9 & ث.الخنساء شارع الربيعي & $\wedge$. \\
\hline ov.1 & 09.9 & OV.r & حديقة بيت & 91 & rv.v & rV. & rv.v & ث.الاصمعي/الثعب & (1) \\
\hline V५.v & V4.0 & Vv.r & كوفيات & QY & 00.4 & $0 \leqslant . \leqslant$ & $0 \leqslant . \Gamma$ & م.طوعة/الحسينية & Ar \\
\hline Yv.A & V५. & VY.A & فلسطين & QT & rr.o & \& & rr.r & أ.السرور/الحسينية & $\Lambda T$ \\
\hline V4.1 & V५. & V.. & كورنيش & $9 \leqslant$ & $\leqslant \wedge .0$ & $\varepsilon v . V$ & $\leq 4.7$ & ث.المهندسين/المهندسين & $\wedge \varepsilon$ \\
\hline$v_{0.9}$ & vo.0 & $V_{0} 0 . \varepsilon$ & مت ومتفرقي & 90 & $01 . r$ & Or.r & 01.1 & ث.صليخ/صليخ & 10 \\
\hline \multirow{2}{*}{\multicolumn{5}{|c|}{ 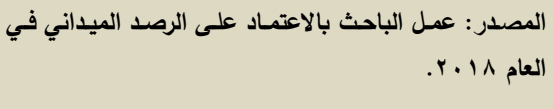 }} & ०^.V & $0 \wedge . \Gamma$ & OV.r & أبتدائية/مدينة الصدر & 14 \\
\hline & & & & & Q৭.r & $0 \wedge . \varepsilon$ & 01.9 & ثانوية/مدينة الصدر & AV \\
\hline
\end{tabular}


المؤتمر العلمي الاولي الحادي عشر

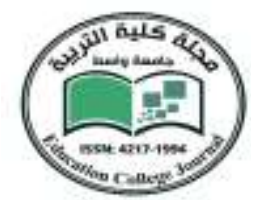

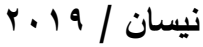

جامعة واسط

مجلــــة كليـــــة التربيــــة

عاشرا: التحليل المكاني والزماني للتلوث الضوضائي لبعض مواقع التسوق المحلية في جانب الرصافة في مدينة بذاد حسب استعمالات الأرض في شهر كانون الثاني:-

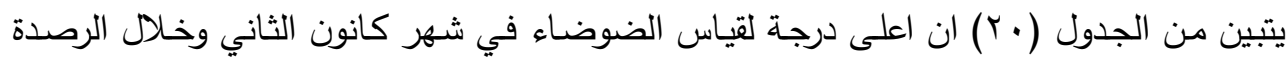

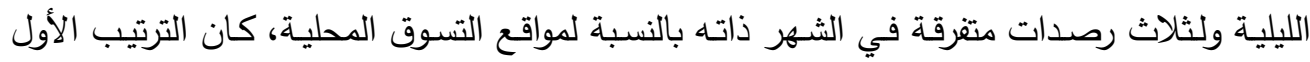
لسوق بغداد الجديدة ويعود ذلك الى ان السوق المذكور يمتد على طول الثارع الرئيسي للمنطقة ذاتها واغلب الضوضساء المرصودة هي بسبب حركة السير لسيارات النقل الخاص والعام، واقل مناطق

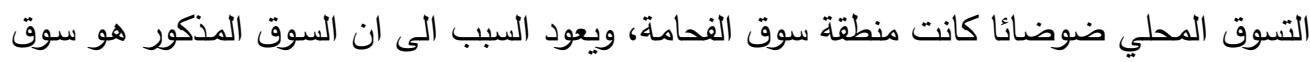

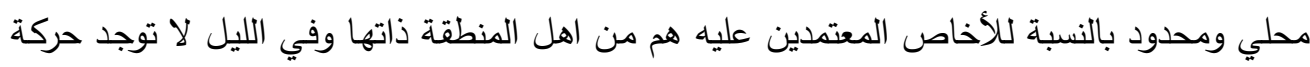

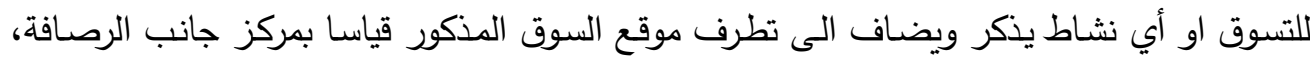
وعلى العموم فأن هذه الأسواق في مدة الرصدة ووقتها فهي ضمن المعيار العالمي والمحلي للتسوق.

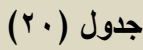

رصدة التاسعة مساءا خلال شهر كانون الثاني لبعض مواقع التسوق المحلية في قاطع

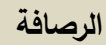

\begin{tabular}{|c|c|c|c|c|}
\hline $\begin{array}{l}\overline{3} \\
\text { 吾 } \\
\text { 武 }\end{array}$ & 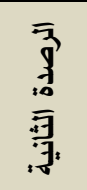 & $\begin{array}{l}\overline{3} \\
\bar{a} \\
\overline{1} \\
\overline{2} \\
\bar{b}\end{array}$ & اسم الموقع & ت \\
\hline rv. & rA.r & r..9 & سوق الفحامة & 99 \\
\hline ri.l & ri.r & ri.r & سوق الراشدية & $9 \mathrm{~V}$ \\
\hline rr.\& & $r \varepsilon . r$ & $r \leqslant .7$ & سوق ؛ الالاف & 91 \\
\hline$\leqslant 1 . v$ & $\varepsilon . r$ & $\leqslant 1 . \varepsilon$ & سوق بغداد الجديدة & 99 \\
\hline ro.9 & $r \leq .9$ & $r \leq . \wedge$ & سوق مدينة الصدر & $1 \ldots$ \\
\hline$r \leqslant . \wedge$ & $r \varepsilon . V$ & $r \varepsilon . \varepsilon$ & سوق باب المعظم & 1.1 \\
\hline$r \leq . \wedge$ & $r \leq .9$ & $r 0.7$ & سوق الحسينية & $1 \cdot r$ \\
\hline
\end{tabular}

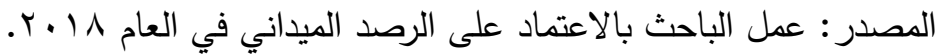


المؤتمر العلمي الاولي الحادي عثر

ج/ارصدة الساعة التاسعة صباحا لقياس التلوث الضوضائي في جانب الرصافة لمدينة بغداد في شهر تموز:أولا: التحليل المكاني والزماني للتلوث الضوضائي لأغلب تقاطعات الطرق في جانب الرصافة في مدينة بغداد حسب استعمالات الأرض في شهر تموز :يتبين من الجدول (Y) ان اعلى قياس للضوضاء في شهر تموز لرصدة التاسعة صباحا بالنسبة لتقاطعات الطرق في جانب الرصافة بوحدة الديسبل كانت لتقاطع (الخلاني) ويعود ذلك الى ان هذا التقاطع من التقاطعات الرئيسية في منطقة الدراسـة وأيضـا تقاطع رئيسي لمركز تجاري رئيسي وأيضـا يتصف بزحام مروري شديد خلال وقت الرصد (التاسعة صباحا) وخلال الرصدات الثثلاثة في شهر تموز ، وعلى التتابع كان اقل المواقع لتقاطعات الطرق تلوثا سمعيا هو تقاطع (ساحة بيروت) ويعود ذلك الى ان التقاطع المذكور انفا يخلو من سبب الزحام الرئيسي في فصل الثتاء بسبب تعطيل الدوام الرسمي للمؤسسات التعليمية وساحة بيروت طريق رئيسي لكثير من الجامعات والكليات، وأيضا عدم وجود مراجعـة لمجمـع الأطباء صباحا فتعد اقل التقاطعـات تلوثا سمعيا، وعلى الرغم من ذلك فأن

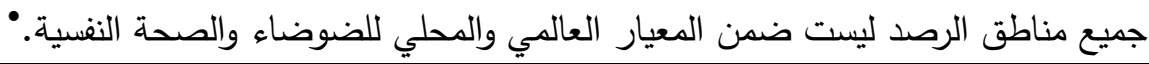

\begin{tabular}{|c|c|c|c|c|c|c|c|c|c|}
\hline \multicolumn{5}{|c|}{ 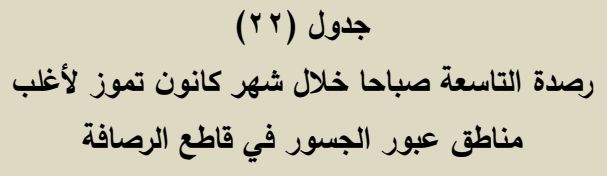 } & \multicolumn{5}{|c|}{ 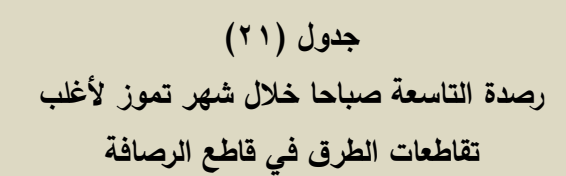 } \\
\hline 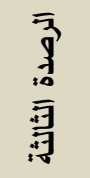 & 牙 & $\begin{array}{l}\overline{3} \\
\overline{3} \\
\overline{3}\end{array}$ & اسم الموقع & ت & 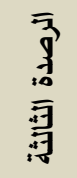 & 可 & $\begin{array}{l}\overline{3} \\
\overline{3} \\
\overline{3}\end{array}$ & الموقع & ت \\
\hline VA.r & $\vee \wedge .1$ & VV.r & المثنى & $r r$ & $\Lambda . . r$ & Vq.r & 11.1 & مطعم & 1 \\
\hline Vr.q & $V \leq .1$ & VT.r & الصرافية & $r r$ & $1 . .9$ & $1 . .1$ & ৩৭.v & شارعة & $r$ \\
\hline$V \leqslant .9$ & V0.1 & $v \varepsilon . r$ & باب المعظم & $r \leq$ & $\vee \wedge . r$ & VQ.r & $1 . .1$ & جامع النداء & $r$ \\
\hline 10.1 & $\Lambda \varepsilon . r$ & Ar.r & السنك & ro & Vo.v & vo.r & Vo.r & تقاطع & $\varepsilon$ \\
\hline vo.r & $v \varepsilon .1$ & vo.r & صليخ & rq & vi.r & $v \ldots o$ & vi.r & سبروت & 0 \\
\hline
\end{tabular}

$v \cdot 9$ 
المؤتمر العلمي الاولي الحادي عشر

\begin{tabular}{|c|c|c|c|c|c|c|c|c|c|}
\hline V9.9 & V৭.\& & VA.r & بذداد الف دار & YV & $\wedge \varepsilon . \wedge$ & $\wedge \varepsilon . V$ & $\Lambda \leq . \Gamma$ & مول النخيل & 7 \\
\hline vo.1 & V^.० & VA.r & ابونؤاس/المذ & rA & A.. 9 & A..r & V9.9 & الثرقي & $v$ \\
\hline VV.q & vV.o & VA.r & الشعب & rq & V५. & vo.1 & v४.r & باب المعظم & $\wedge$ \\
\hline VV.r & $v_{0.9}$ & $V \varepsilon .7$ & البنوك/الوزيرية & $r$. & 11.0 & ^1.£ & Ar.r & النهاطع & 9 \\
\hline \multirow{2}{*}{\multicolumn{5}{|c|}{ رصدة التاسعة صباحا خلال شهر تموز لأغلب الأحياء الصناعية في }} & Ar.l & ^1.\& & Aו.r & سوق الحي & 1. \\
\hline & & & & & $V \varepsilon . r$ & Vr.e & $V \varepsilon . r$ & المهندسين & 11 \\
\hline 牙 & 牙 & 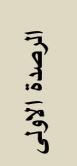 & اسم الموقع & $ت$ & $9 . .1$ & A9.r & $9 . . r$ & الخلاني & ir \\
\hline vo.r & vr.o & $v \varepsilon . r$ & بذداد الجديدة & ri & Av.V & AV.\& & $\wedge \wedge . \wedge$ & ساحة الوثبة & ir \\
\hline จ५.^ & VV.r & V५.น & شيخ عمر & rr & 11.9 & A..r & 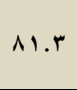 & سينماء & $1 \leqslant$ \\
\hline$v \cdot .0$ & vi.e & $v \cdot . r$ & باب الشرقي & $r \varepsilon$ & $\vee 0 . \wedge$ & vo.A & V५.r & الدرويش & 10 \\
\hline ס.8. & Tะ.T & $\varphi . r$ & الحسينية & ro & V५.1 & $v \varepsilon . \wedge$ & vo.r & القشتل مع & 17 \\
\hline vi.r & $v \cdot . r$ & $v . .1$ & الطالبية & ri & vo.1 & v४. 9 & Vv.r & مشتل مع & iv \\
\hline 71.7 & TV. & in.r & شارع فلسطين & rv & va.1 & VA. 9 & VA.r & ميسلون & 11 \\
\hline$\pi . r$ & Tr.\& & $71 . r$ & باب المعظم & rs & VA.1 & VV. $q$ & VV.r & ملعب & 19 \\
\hline \multirow{2}{*}{\multicolumn{4}{|c|}{ 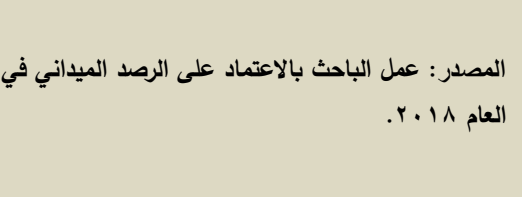 }} & & Vr.r & vo.1 & $V \varepsilon . r$ & باب المعظم & $r$. \\
\hline & & & & & $v 1.9$ & VY.r & vi.r & مدينة الطب & rI \\
\hline
\end{tabular}

ثانيا: التحليل المكاني والزماني للتلوث الضوضائي لأغلب مناطق عبور الجسور في جانب الرصافة في مدينة بغداد حسب استعمالات الأرض في شهر تموز :-

يتبين من الجدول (Yr) ان اعلى درجة لرصد الضوضـاء في جانب الرصافة في شهر تموز

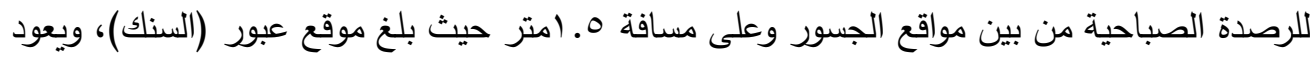

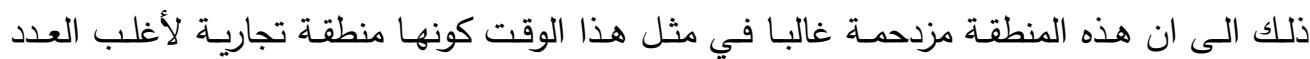


المؤتمر العلمي الاولي الحادي عشر

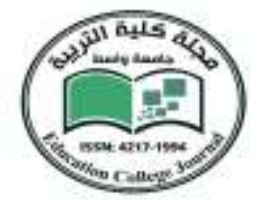

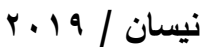

جامعة واسط

مجلــــة كليـــــة التربيـــــة

والحاجيات المنزلية وكماليات السيارات واغلب العدد الكمالية الضرورية في بغداد، وأيضا كونها منطقة عبور رئيسية بين الكرخ والرصافة، وعلى الترتيب فأن اقل مناطق جسور العبور تلوثا ضوضائيا كانت (الصرافية)، ويعود ذلك الى ان هذه النقطة هي نقطة عبور حصرا وليس منطقة تجارية ومراكز تسوق مجاور لمنطقة العبور وان الضوضاء التي تم رصدها هي بسبب عبور السيارات والضوضناء المتولد عنها.

ثالثا: التحليل المكاني والزماني للتلوث الضوضائي لأغلب الاحياء الصناعية في جانب الرصافة في مدينة بغداد حسب استعمالات الأرض في شهر تموز :يتبين من الجدول (Tr) ان اعلى درجة لقياس الضوضاء في الاحياء الصناعية في مدينة بغداد لجانب الرصافة في شهر تموز خلال الرصدة الصباحية وللرصدات الثلاثة ان نقطة الحي الصناعي (لثيخ عمر) سجل اعلى تلوث ضوضائي وعلى التتابع، اقل تلوث ضوضائي سجل بالنسبة للأحياء الصناعية كان للحي الصناعي (باب المعظم) ويعود ذلك الى ان الاقبال على الحي الصناعي المذكور ليس بالزحام الثديد، بسبب طبيعة حجم الحي الصناعي وأيضا بسبب تخصص الحي الصناعي واقتصاره على نوع واحد من الصيانة فجعل الضوضاء المتولدة عنه قليلة اذا ما قورن بغيره من الاحياء الصناعية وهذا لا يطابق المعايير العالمية والمحلية لقياس الضوضاء بأستثناء الحي الصناعي في باب المعظث رابعا: التحليل المكاني والزماني للتلوث الضوضائي لمداخل الجامعات والكليات في جانب الرصافة في مدينة بغداد حسب استعمالات الأرض في شهر تموز:يتبين من الجدول (ع r) ان اعلى تلوث للضوضاء عند مداخل الجامعات وعلى مسافة ب متر كان عند مـدخل (الجامعـة المستتصـرية) ويعـود ذلك الى ان الضوضـاء المرصـودة ليس بسـبب الـدوام الرسمي، وذلك لان الدوام معطل للطلبة في هذا الوقت من الرصد ولكن الضوضـاء المرصودة بفعل حركة السير والزحام المروري في سـاعة الرصد، وعلى الترتيب فـأن اقل المنـاطق رصدا بالنسبة فئس لمداخل الجامعات كان مدخل (كليـة الهندسـة مستصـرية) ويعود ذلك الى عدم وجود زحام لحركة المرور كالايـام في الرصدة الثـتوية بسبب تعطيل الدوام الرسمي للطلبة، وأيضـا ليس هنالك مبرر لوجود زحام مروري اذا لم يكن هنالك حركة للطلبة في الجامعات في جانب الرصافة وعلى الرغم من ذلك فأن درجة الضوضاء التي تم رصدها فهي ضمن المعيار العالمي والمحلي للصحة العراقية لقياس 
المؤتمر العلمي الدولي الحادي عشر

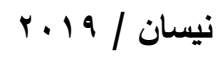

جامعة واسط

مجلــــة كليــــة التربيــــة

\begin{tabular}{|c|c|c|c|c|c|c|c|c|c|}
\hline \multicolumn{6}{|c|}{ رصدة التاسعة صباحا خلال شهر تموز لأغلب مداخل المستثفيات في } & \multicolumn{4}{|c|}{ 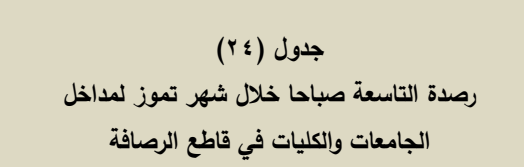 } \\
\hline $\begin{array}{l}\overline{3} \\
\text { 志 } \\
\text { 牙 } \\
\text { 滕 }\end{array}$ & 牙 & $\begin{array}{l}\overline{3} \\
\overline{1} \\
\overline{3} \\
\overline{3}\end{array}$ & اسم الموقع & $ت$ & 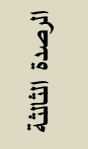 & 牙 & $\overline{\bar{s}}$ & اسم الموقع & $ت$ \\
\hline vo.r & $V \leqslant .0$ & VT.r & مدينة الطب & •. & 00.9 & ๑૫.६ & $00 . r$ & مجمع باب المعظم & rq \\
\hline V०.० & $\vee \curlyvee . \wedge$ & V०. $\varepsilon$ & الثيخ زايد & 01 & 00.1 & or.o & $0 \leq . \varepsilon$ & كلية الهندسة & $\varepsilon$. \\
\hline V^.r & Vq.9 & $\vee \wedge . \vee$ & الكندي & or & $7 \cdot .9$ & $7 . \varepsilon$ & Y..r & الفنون الجميلة & $\leqslant 1$ \\
\hline$\vee 9 . \wedge$ & $\wedge . r$ & Vq.r & 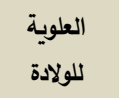 & or & $v \cdot .7$ & $\vee 1.7$ & vi.r & الجامعة المستنصرية & $\varepsilon r$ \\
\hline$V \varepsilon . Y$ & vo.A & $V \varepsilon . r$ & ابن البيطار & $0 \leqslant$ & 79.0 & $\checkmark \wedge .9$ & $99 . \varepsilon$ & الجامعة العراقية & $\varepsilon r$ \\
\hline Vr. $\varepsilon$ & $\vee 1.1$ & VY.r & ابن القفل & 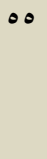 & 10.9 & หร.V & 70.7 & الإدارة واقتصاد بغداد & \& \\
\hline$\vee 9.9$ & $\vee 9.9$ & $\wedge \cdot . r$ & الزهزاوي & 04 & $7 \varepsilon .1$ & 84.9 & 97 & مستتصرية الإدارة اقتصاد & $\leq 0$ \\
\hline$\vee \wedge .1$ & $\vee \vee . \wedge$ & V^.r & ابن البلدي & ov & $v \cdot . \varepsilon$ & vi.r & $v \cdot .7$ & الجامعة التكنلوجية & ะ ฯ \\
\hline 79.9 & $v \cdot . \Lambda$ & $v \cdot r r$ & شهاب & $0 \wedge$ & 74.0 & TV.V & 70.7 & معهد تكنلوجيا زعفرانية & $\varepsilon v$ \\
\hline \multirow{2}{*}{\multicolumn{4}{|c|}{ 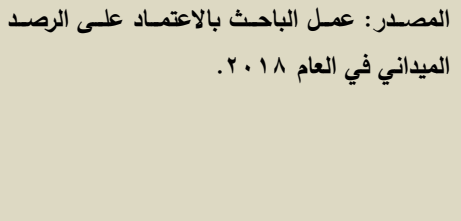 }} & & 79.9 & vi.1 & $v \cdot .0$ & معهة الإدارة & $\varepsilon \wedge$ \\
\hline & & & & & 71.8 & YY.E & 71.8 & القانون/مستية & $\leqslant 9$ \\
\hline
\end{tabular}


المؤتمر العلمي الاولي الحادي عشر

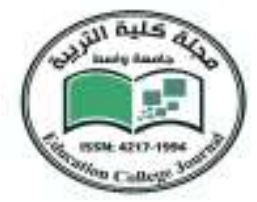

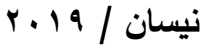

جامعة واسط

مجلــــة كليــــة التربيــــة

خامسا: التحليل المكاني والزماني للتلوث الضوضائي لأغلب مداخل المستثفيات في جانب الرصافة في مدينة بغداد حسب استعمالات الأرض في شهر تموز:-

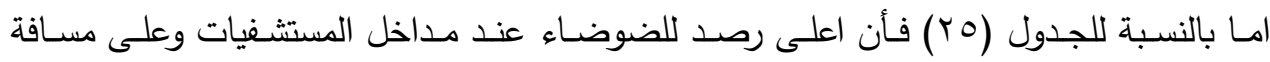

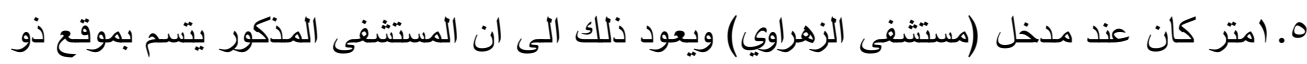

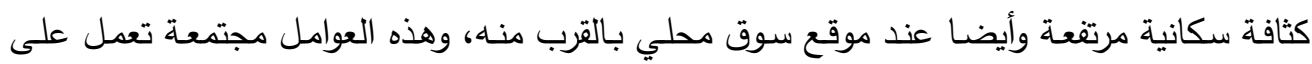

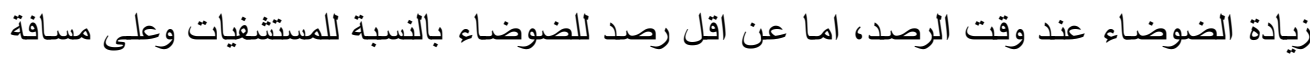

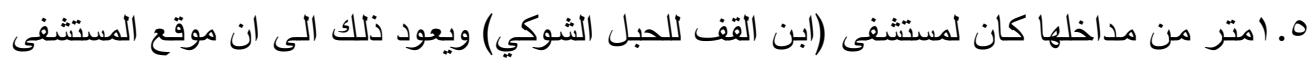

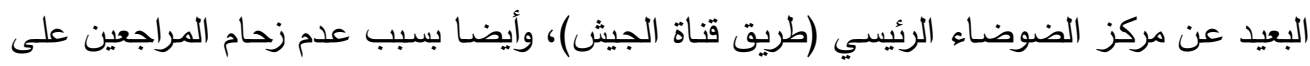

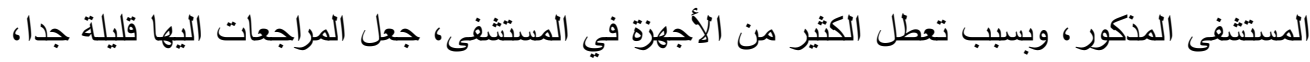

وعلى الرغم من ذلك فأن الضوضاء الصادرة لا تقع ضمن المعيار العالمي والمحلي المسموح به.

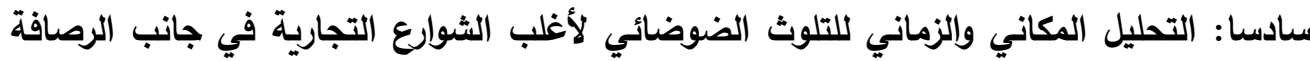
في مدينة بغداد حسب استعمالات الأرض في شهر تموز:-

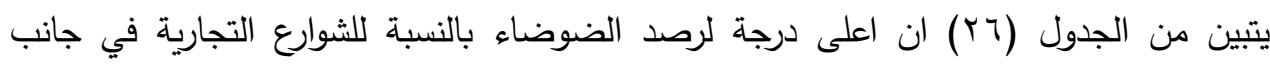

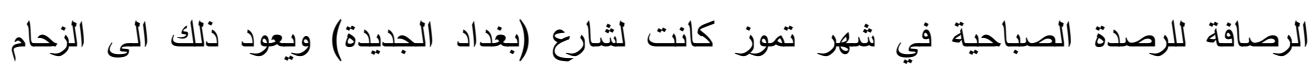

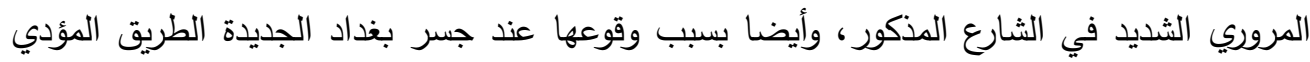

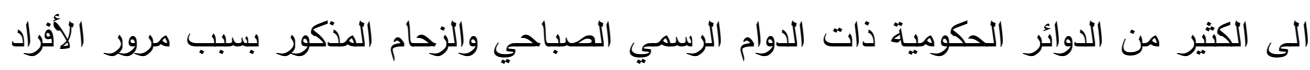

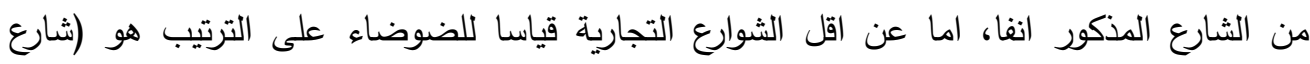

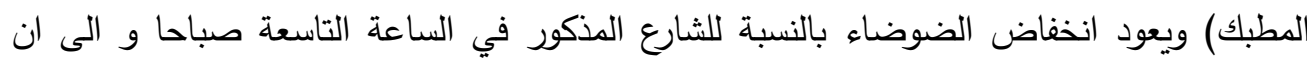

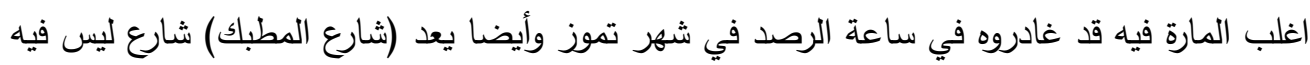

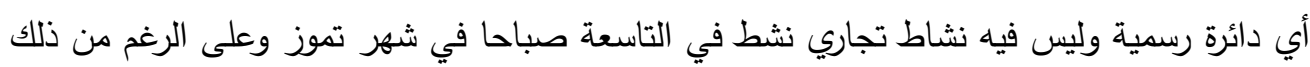
فان مستوى الضوضاء ليس ضمن المعيار العالمي والمحلي للضوضاء. 
المؤتمر العلمي الدولي الحادي عشر

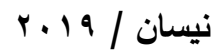

جامعة واسط

مجلــــة كليــــة التربيـــة

\begin{tabular}{|c|c|c|c|c|c|c|c|c|c|}
\hline \multicolumn{6}{|c|}{ 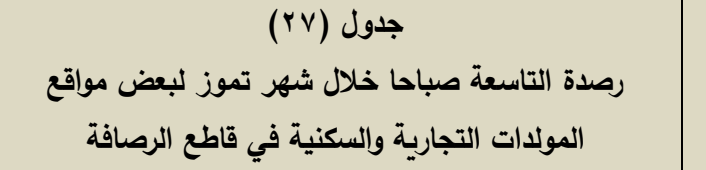 } & \multicolumn{4}{|c|}{ 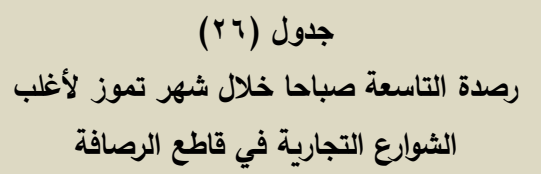 } \\
\hline 牙哥 & 可哥 & 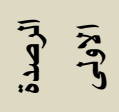 & الموقع & $ت$ & 勇哥 & 牙哥 & $\overline{3}$ & اسم الموقع & ت \\
\hline $\begin{array}{c}119 . \\
9\end{array}$ & $\begin{array}{c}11 \mathrm{~V} . \\
\wedge\end{array}$ & 110. & الشعب & 79 & vV.r & $\begin{array}{c}\vee \wedge . \\
\wedge\end{array}$ & Vv.r & شارع البنوك & ०q \\
\hline${ }_{V}^{r} \cdot$ & $\begin{array}{l}1 \times 1 . \\
\varepsilon\end{array}$ & $\begin{array}{l}i r \cdot . \\
\varepsilon\end{array}$ & صولدات & $v$. & $\wedge . . \wedge$ & $\begin{array}{c}A \cdot . \\
r\end{array}$ & V৭.r & شارع فلسطين & 7. \\
\hline $\begin{array}{c}|r| . \\
1\end{array}$ & $\begin{array}{c}119 . \\
9\end{array}$ & $\begin{array}{c}111 . \\
7\end{array}$ & بولدات & vi & Ar.A & $\begin{array}{c}\wedge \varepsilon . \\
\wedge\end{array}$ & Ar.\& & بغاد الجديدة & 11 \\
\hline $\begin{array}{c}111 . \\
\varepsilon\end{array}$ & $\begin{array}{c}119 . \\
0\end{array}$ & $\begin{array}{l}119 . \\
8\end{array}$ & مولدات & vr & va.1 & $\begin{array}{l}\vee \wedge . \\
\wedge\end{array}$ & V q.r & شارع عدن & Tr \\
\hline $\begin{array}{c}11 \varepsilon \\
0\end{array}$ & $\begin{array}{c}11 r . \\
0\end{array}$ & $\begin{array}{l}11 r . \\
0\end{array}$ & مولدات & $v^{r}$ & จ५.A & $\begin{array}{l}\text { vo. } \\
\wedge\end{array}$ & V५.r & شارع المكاتب & זי \\
\hline $\begin{array}{c}1.9 . \\
9\end{array}$ & $\begin{array}{c}11 \% . \\
1\end{array}$ & $\begin{array}{c}111 . \\
\varepsilon\end{array}$ & البلديات & $v \varepsilon$ & vi.\& & $\begin{array}{l}v_{1} . \\
\wedge\end{array}$ & $v . .1$ & شارع المطبك & T \\
\hline $\begin{array}{c}11 . \\
9\end{array}$ & $\begin{array}{c}1.9 . \\
9\end{array}$ & $\begin{array}{c}1 \cdot 1 . \\
0\end{array}$ & مولادات & vo & 79.1 & $\begin{array}{c}r 1 . \\
v\end{array}$ & 79.0 & شارع الربيعي & io \\
\hline $\begin{array}{c}11 . \\
r\end{array}$ & $\begin{array}{c}1.9 . \\
1\end{array}$ & $\begin{array}{c}1 \cdot 1 . \\
\wedge\end{array}$ & مولدات & vi & 78.9 & $\begin{array}{c}7 \varepsilon . \\
1 .\end{array}$ & $70 . \mathrm{V}$ & شارع صليخ & 74 \\
\hline $\begin{array}{c}11 . \\
0\end{array}$ & $\begin{array}{c}1.9 . \\
1\end{array}$ & $\begin{array}{c}1.9 . \\
5\end{array}$ & الحسينية & vV & v 9.7 & $\begin{array}{l}\text { va. } \\
\varepsilon\end{array}$ & v 9.0 & شيسلون التوت & iv \\
\hline \multicolumn{5}{|c|}{ 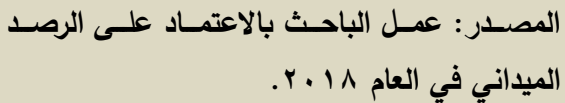 } & V৭.r & A.. & 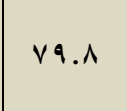 & شارع كرادة داخل & 71 \\
\hline
\end{tabular}


المؤتمر العلمي الاولي الحادي عشر

سابعا: التحليل المكاني والزماني للتلوث الضوضائي لبعض مواقع المولدات التجارية والسكنية في

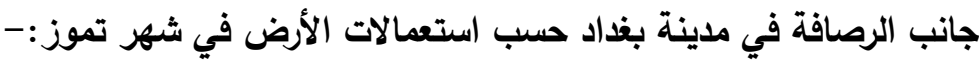

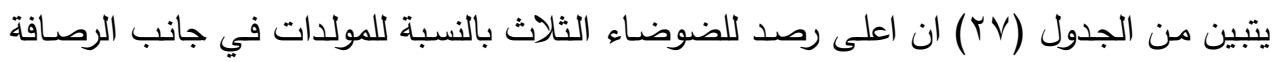
لشهر تموز وخلال رصدة التاسعة صباحا كانت لموقع مولدات (مدينة الصدر) ويعود ذلك الى العزم

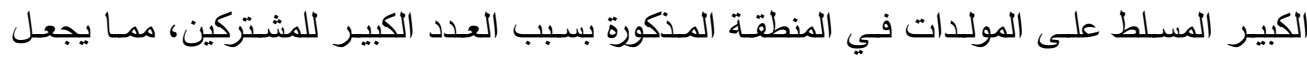

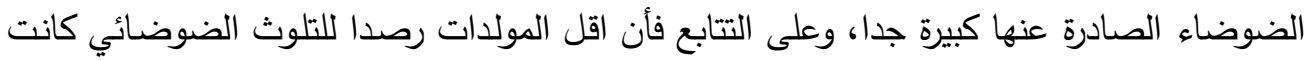

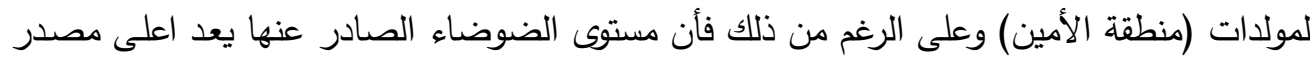
للضوضاء في جانب الرصافة قياسا بالاستخدامات الأخرى، وعليه لم تطابق المعيار العالمي والمحلي المستوى الضوضاء المقبول. ثامنا: التحليل المكاني والزماني للتلوث الضوضاءئي لبعض مواقع المدارس المتنوعة في جانب الرصافة في مدينة بغداد حسب استعمالات الأرض في شهر تموز :-

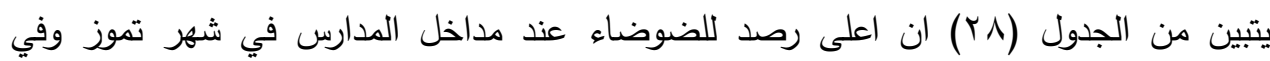

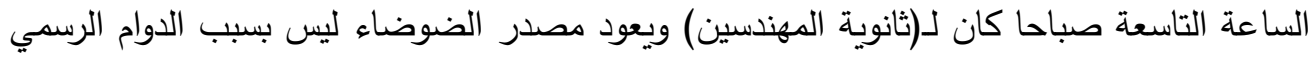

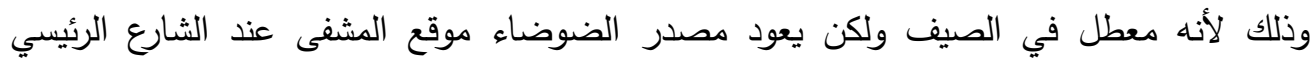
المؤدي الى الباب الثرقي مركز جانب الرصافة، اما عن اقل تلوث ضوضائي بالنسبة لدذاخل

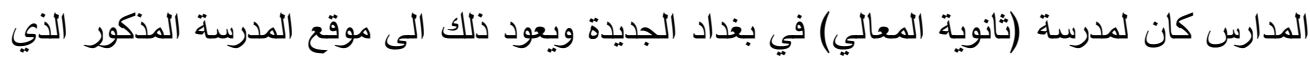

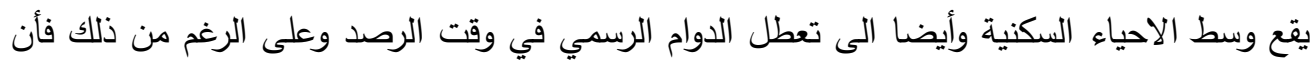

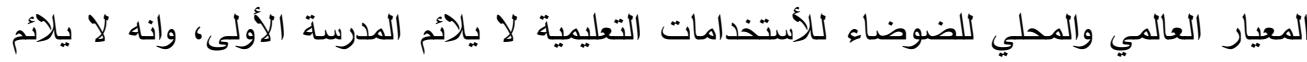
المدرسة الثانية المعيار العالمي وينطبق عليها المعيار المحلي. 
المؤتمر العلمي الدولي الحادي عشر

\begin{tabular}{|c|c|c|c|c|c|c|c|c|c|}
\hline \multicolumn{5}{|c|}{ 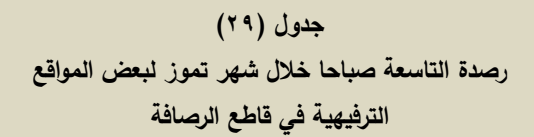 } & \multicolumn{5}{|c|}{ 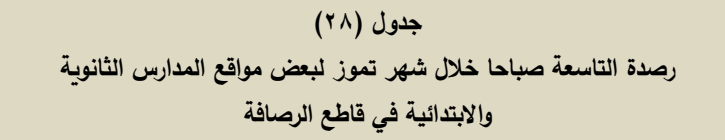 } \\
\hline 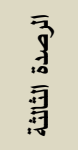 & 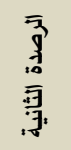 & 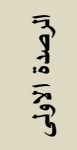 & اسم الموقع & ت & 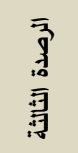 & 勇 & $\begin{array}{c}\overline{3} \\
\overline{1} \\
\overline{3}\end{array}$ & اسم الموقع & ت \\
\hline V५. & VA.q & V५.० & مدينة العاب & $\wedge \wedge$ & Or. 1 & $0 . . r$ & $01 . \varepsilon$ & ث.المعالي/بغداد الجديدة & vA \\
\hline$V \varepsilon .0$ & vo. $\varepsilon$ & $v \varepsilon . r$ & مدينة العاب & $\wedge 9$ & or.v & 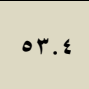 & O\&.r & أ.الخليج/منطقة الدرويش & va \\
\hline$T \leq .1$ & $10 . \varepsilon$ & in.r & الجزيرة & q. & ०१.v & OV.q & OV.T & ث.الخنساء شارع الربيعي & A. \\
\hline $7 . .1$ & 71.1 & TY.Y & حديقة بيت & 91 & 90.1 & $7 \leqslant .7$ & $7 v .4$ & ث.الاصمعي/الشب & $\Lambda_{1}$ \\
\hline$\varepsilon$ & «1.r & $\varepsilon \ldots 1$ & ومقيات & Qr & १^.r & 74.V & $7 v .4$ & م.طوعة/الحسينية & Ar \\
\hline$v . .1$ & 79.4 & in.r & فلسطين & q4 & $9 . .1$ & $09 . v$ & 1.1 & أ.السرور/الحسينية & Ar \\
\hline $0 \leqslant .7$ & 0.. & 00.1 & كورنيش & $9 \leq$ & $v \cdot . r$ & vi.r & $v \cdot . r$ & ث.المهنسين/المهندسين & $\Lambda \varepsilon$ \\
\hline $0 \leqslant .0$ & OV.r & $09 . \%$ & مت وملفرقة & 90 & 79.7 & $v . .4$ & $v \cdot . r$ & ث.صليخ/صليخ & 10 \\
\hline \multicolumn{5}{|c|}{ المصدر: عمل الباحث بالاعتماد على الرصد الميداني في } & $v \cdot .7$ & $v \cdot . r$ & $79 . r$ & أبتدائية/مدينة الصدر & 14 \\
\hline \multicolumn{5}{|c|}{ 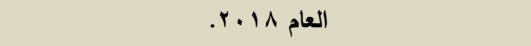 } & $79 . r$ & $\curlyvee \wedge . \wedge$ & TV.0 & ثانوية/مدينة الصدر & $\Lambda \mathrm{V}$ \\
\hline
\end{tabular}


المؤتمر العلمي الاولي الحادي عثر

تاسعا: التحليل المكاني والزماني للتلوث الضوضائي لبعض المواقع الترفيهية في جانب الرصافة في مدينة بغداد حسب استعمالات الأرض في شهر تموز :يتبين من الجدول (Yq) ان اعلى تلوث ضوضائي للمواقع الترفيهية في جانب الرصافة لشهر تموز في الساعة التاسعة صباحا كان لـ(لمدينة السندباد) وذلك بسبب ضوضاء الألعاب التي تعمل داخل الموقع الترفيهي، وان اقل رصد للضوضاء بالنسبة للمواقع الترفيهية في جانب الرصافة كان لـ(كوفيات

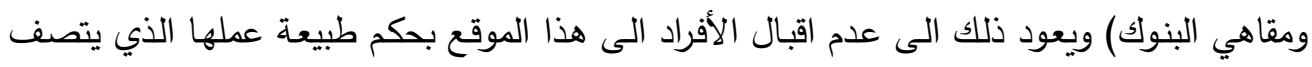
بأنه وقتها عصرا وليس صباحا، وعلى الرغم من ذلك فأن الموقع الأول ليس ضمن المعيار العالمي والمحلي للضوضاء اما الموقع الثاني فأنه لا يقع ضدن المعيار العالمي ولكنه ضمن المعيار المحلي للضوضاء للأستخدامات الترفيهية. عاشرا: التحليل المكاني والزماني للتلوث الضوضائي لبعض مواقع التسوق المحلية في جانب الرصافة في مدينة بغداد حسب استعمالات الأرض في شهر تموز:-

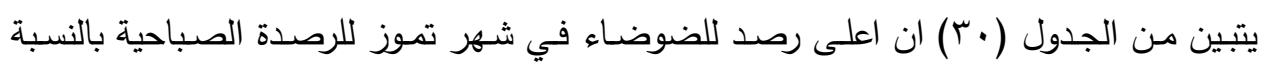
لأمـاكن التسوق المحلي في قاطع الرصافة كان لـ(لسوق باب المعظم) وذلك بحكم موقعها المركزي

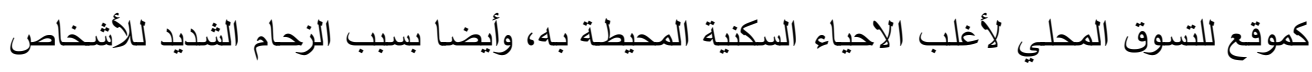
الوافدين اليه وبسبب كونه علوة للتسوق المحلي، اما عن اقل مركز للتسوق المحلي رصدا للضوضاء كان لــ(سوق الفحامـة) ويعود ذلك الى تطرف موقع السوق المـكور وأيضـا الى بعدها عن أمـاكن السكن المحيطة به وأيضا بسبب الضوضاء المرصود فيه يعود الى الأشخاص المحليين الذين يقطنون بالقرب من السوق، وعلى الرغم من ذلك فأن مستوى الضوضاء المرصود ليس ضمن المعيار العالمي والمحلي للضوضاء بالنسبة لمراكز التسوق المحلية. 
جدول (r) (r)

رصدة التاسعة صباحا خلال شهر تموز لبعض مواقع التسوق المحلية في

\begin{tabular}{|c|c|c|c|c|}
\hline \multicolumn{5}{|c|}{ قاطع الرصافة } \\
\hline $\begin{array}{l}\overline{3} \\
\text { 吾 } \\
\text { 翥 }\end{array}$ & 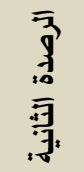 & $\begin{array}{l}\overline{3} \\
\overline{3} \\
\overline{3} \\
\bar{\zeta}\end{array}$ & اسم الموقع & ت \\
\hline VY.V & $v \leq .1$ & VY.O & سوق الفحامة & 97 \\
\hline vi.1 & $v \cdot . v$ & $V \cdot . r$ & سوق الراثدية & $9 V$ \\
\hline ^०.r & $\Lambda \leq . \varepsilon$ & Ar.r & سوق ؛ الالاف & $9 \wedge$ \\
\hline VT.r & VY.r & V५.r & سوق بغداد & 99 \\
\hline$\Lambda . . v$ & AI.r & $\Lambda \cdot . r$ & سوق مدينة & $1 \ldots$ \\
\hline ง . & ง५.। & AV.\& & سوق باب المعظم & 1.1 \\
\hline 10.r & $\Lambda \leq .0$ & Ar.s & سوق الحسينية & $1 \cdot r$ \\
\hline
\end{tabular}

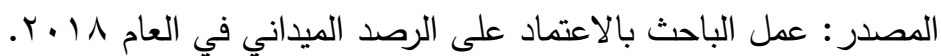
د//رصدة الساعة التاسعة مساءا لقياس التلوث الضوضائي في جانب الرصافة لمدينة بغداد في شهر تموز:أولا: التحليل المكاني والزماني للتلوث الضوضائي لأغلب تقاطعات الطرق في جانب الرصافة في مدينة بغداد حسب استعمالات الأرض في شهر تموز :يتبين من الجدول (1) ان اعلى درجة للتلوث الضوضائي في جانب الرصافة لشهر تموز خلال الرصدات المسائية الثلاثة بالنسبة لتقاطعات الطرق كانت لتقاطع (ساحة بيروت) ويعود ذلك الى ان هذا التقاطع يعد من التقاطعات المزدحمة في جانب الرصافة كونه يعد ممر رئيسي لكثير من المراكز

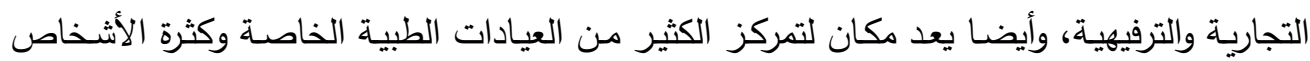

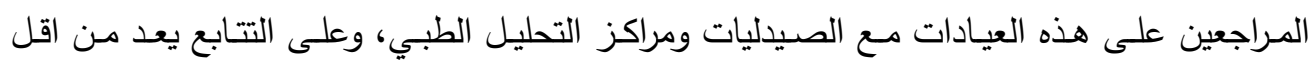

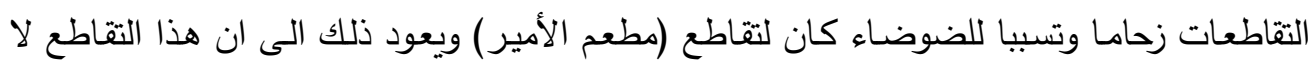


المؤتمر العلمي الاولي الحادي عثر

نيسان / 19
جامعة واسط

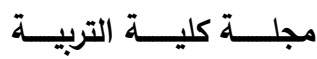

يشهد حركة مرورية قوية في ساعة الرصد وعلى الرغم من ذلك فأن مستوى الضوضاء المرصود ليس

مطابق للمعايير العالمية والمحلية للضوضاء. •

\begin{tabular}{|c|c|c|c|c|c|c|c|c|c|}
\hline \multicolumn{5}{|c|}{ رصدة التاسعة مساءا خلال شهر تموز لأغلب مناطق عبور الجسور في قاطع } & \multicolumn{5}{|c|}{ رصدة التاسعة مساءا خلال شهر تموز لأغلب تقاطعات الطرق في } \\
\hline 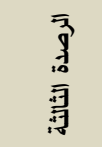 & 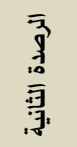 & 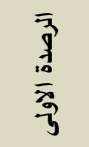 & اسم الموقع & $ت$ & 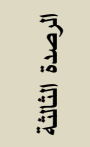 & 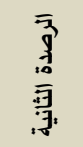 & 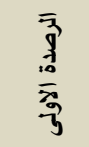 & اسم الموقع & ت \\
\hline $7 . .9$ & $7 r .9$ & Ir.r & المثنى & YY & 71.0 & ri.r & TY.Y & مطعم الامير & 1 \\
\hline vi.v & VY.q & VY.r & الصرافية & $r \mu$ & iv.q & 71.0 & 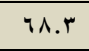 & شارع الصحة & $r$ \\
\hline 10.9 & $1 \leq . \wedge$ & 90.0 & باب المعظم & $r \leqslant$ & vo.1 & $v \leqslant .0$ & V५.r & جامع النداء & $r$ \\
\hline IV.A & 71.1 & 79.9 & السنك & ro & vr.o & $v \leq .1$ & Vr.r & تقاطع الموال & $\varepsilon$ \\
\hline 71.1 & IV.A & 79.9 & صليخ & $r q$ & Vฯ.Y & vV.1 & จ५.r & ساحة بيروت & 0 \\
\hline VI.r & $v \cdot .9$ & vi.r & بغداد الف دار & $r v$ & Vฯ.Y & $v_{0.9}$ & $v 0.0$ & مول النخيل & 7 \\
\hline VV.A & vV.V & V५.r & ابونؤاس/المنصور & $r \wedge$ & $v \cdot .9$ & $v 1.1$ & $v \cdot . r$ & الباب الثرقي & $v$ \\
\hline$v \cdot .9$ & VY.O & vi.0 & الثعب & $r q$ & $7 \Lambda . \wedge$ & IV.V & TV.r & باب المعظم & $\Lambda$ \\
\hline vi.r & VY.r & $v \cdot . r$ & البنوك/(لوزيرية & $r$. & TV.r & 78.9 & 17.7 & تقاطع النهضة & 9 \\
\hline \multirow{2}{*}{\multicolumn{5}{|c|}{ رصدة التاسعة مساءا خلال شهر تموز لأغلب الأحياء الصناعية في قاطع }} & $v \leqslant .9$ & $v_{0.1}$ & $V \varepsilon . r$ & سوق الحي & 1. \\
\hline & & & & & vi.1 & $v \cdot .9$ & vi.e & المهندسين & 11 \\
\hline الراثلة & الثانية & الرولى & اسم الموقع & ت & vi.1 & Vr.q & VY.r & الخلاني & Ir \\
\hline$\leq 0.1$ & $\leq 0.9$ & $\varepsilon 0.1$ & بغداد الجديدة & $r$ & $v \cdot .9$ & vi.e & $v \cdot .1$ & ساحة الوثبة & ir \\
\hline$\leqslant$ Y.O & $\varepsilon r .1$ & $\varepsilon r . r$ & شيخ عمر & $r r$ & vi.r & $v 1.9$ & VY.1 & سينما البيضاء & $1 \varepsilon$ \\
\hline$\leqslant 9.1$ & $\varepsilon \wedge .9$ & $\varepsilon 9 . \varepsilon$ & باب الثرقي & $r \varepsilon$ & $v 0.1$ & $V \leqslant .9$ & $V \varepsilon . Y$ & الارويش & 10 \\
\hline or.A & or.t & or.r & الحسينية & ro & $v \varepsilon . \wedge$ & $V \varepsilon . r$ & Vr.q & المشتل مع & 17 \\
\hline Tr.Y & $\pi 1 . V$ & $71 . r$ & الطالبية & ry & VI.V & VY.r & VI.r & مشتل مع بلديات & IV \\
\hline 71.1 & Tr.V & Tr.r & شارع فلسطين & $r v$ & vV.A & V५.V & VA.Y & ساحة ميسلون & 11 \\
\hline 7.9 & ir.r & $\$ 11$ & باب المعظم & $r \wedge$ & $v \leqslant .1$ & $\mathrm{v} \cdot . \wedge$ & $\mathrm{v} 0.0$ & ملعب الثعب & 19 \\
\hline \multirow{2}{*}{\multicolumn{5}{|c|}{ المصدر: عمل الباحث بالاعتماد على الرصد الميداني في العام ^ ــــ. }} & 94.1 & 10.0 & iv.v & باب المعظم & $r$. \\
\hline & & & & & $09 . \varepsilon$ & 7.99 & $7 . . Y$ & مدينة الطب & rl \\
\hline
\end{tabular}


المؤتمر العلمي الدولي الحادي عشر

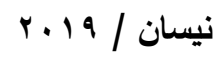

\section{جامعة واسط}

مجلــــة كليـــة التربيـــة

ثانيا: التحليل المكاني والزماني للتلوث الضوضائي لأغلب مناطق عبور الجسور في جانب الرصافة في مدينة بغداد حسب استعمالات الأرض في شهر تموز :-

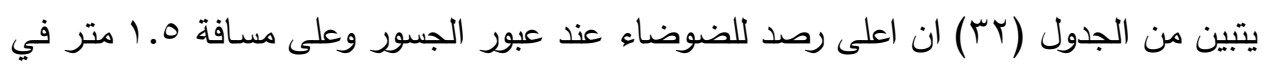
جانب الرصافة لثهر تموز وعند الساعة التاسعة مساءا كانت لجسر العبور (أبو نؤاس/الهنصور )

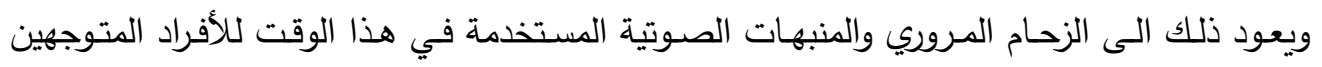

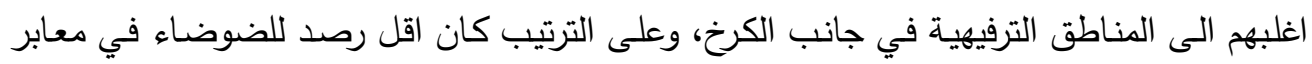
الجسور لـ(باب المعظم) ويعود ذلك الى قلة الزحام المروري والمنبهات الصوتية المتولدة عنها، وأيضا

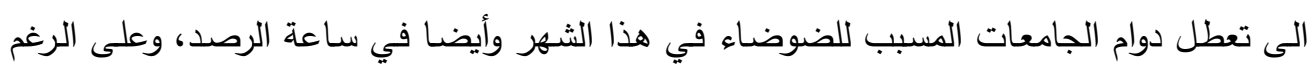
من ذلك فأن رصد الضوضاء المرصود غير موافق للمعايير العالمية والمحلية للضوضاء.

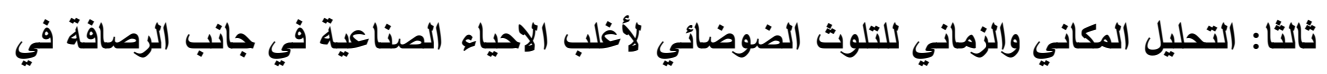
مدينة بذاد حسب استعمالات الأرض في شهر تموز:-

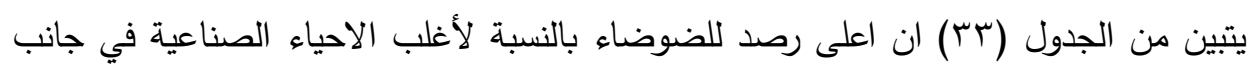

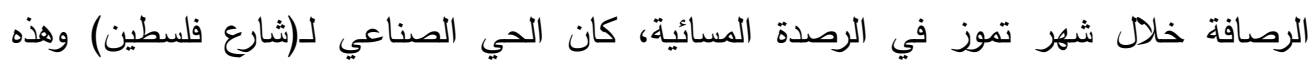

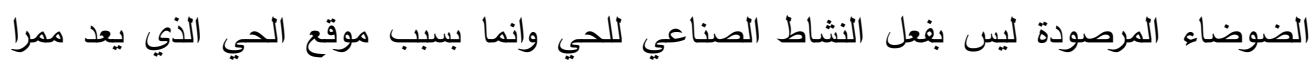

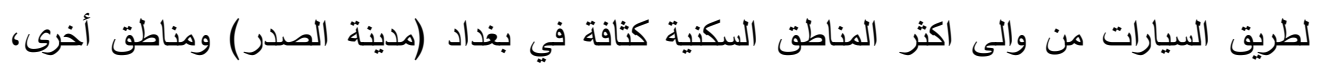

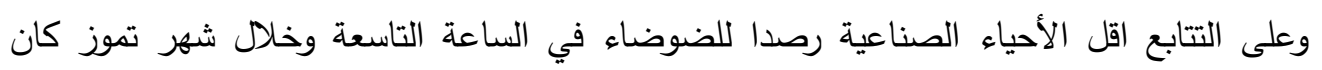

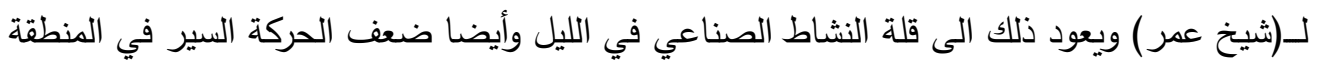

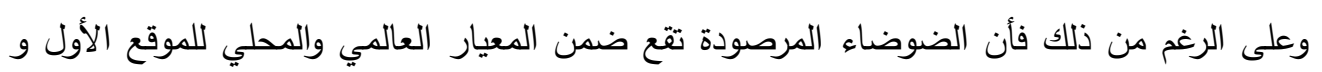

$$
\text { • الموقع الأخير . }
$$

رابعا: التحليل المكاني والزماني للتلوث الضوضائي لمداخل الجامعات وإلكليات في جانب الرصافة في مدينة بغداد حسب استعمالات الأرض في شهر تموز :-

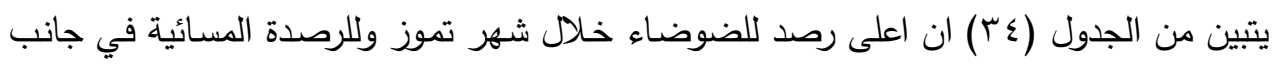

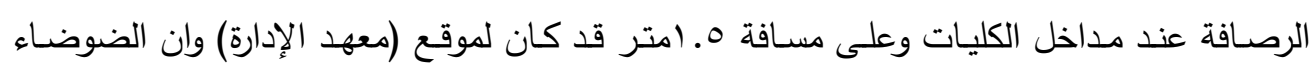

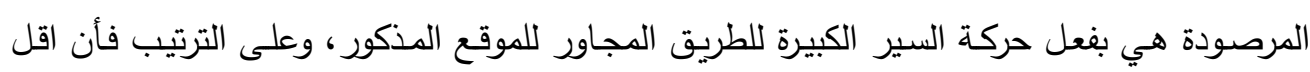

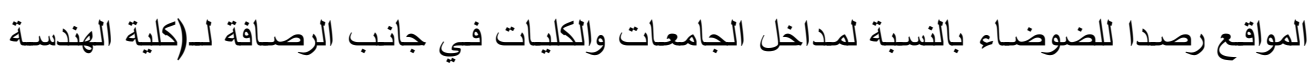


المؤتمر العلمي الدولي الحادي عشر

مستصرية) ويعود ذلك الى عدم وجود دوام مسائي في وقت الرصد وأيضـا الى قلة الحركة المروريـة ليلا عند موقع الجامعة المذكور ، وعلى الرغم من ذلك فأن مستوى الضوضناء المرصود ليس ضمن وهن

المعيار العالمي المقبول للضوضاء. •

\begin{tabular}{|c|c|c|c|c|c|c|c|c|c|}
\hline & لأغلب ، & شاطع تمع الر & اسعة مساءا خد المستشفيات & & & 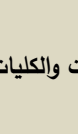 & 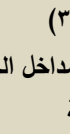 & سعة مساءا خلال شهر ت & \\
\hline 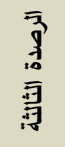 & $\begin{array}{l}\overline{3} \\
1 \\
10 \\
\overline{7} \\
.79\end{array}$ & $\begin{array}{l}\overline{3} \\
\overline{1} \\
\overline{3} \\
\text { bे }\end{array}$ & اسم الموقع & ت & $\begin{array}{l}\overline{3} \\
70 \\
\text { 牙 } \\
\text { 音 }\end{array}$ & 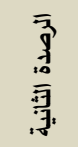 & 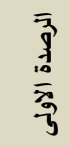 & اسم الموقع & $ت$ \\
\hline 79.4 & 79.9 & $\curlyvee \wedge . \vee$ & مدينة الطب & o. & $0 ., 1$ & o..r & $0 . . \varepsilon$ & مجمع باب المعظم & rq \\
\hline vi.t & VY.A & $v \cdot . r$ & الشيخ زايد & 01 & $\leqslant 9.0$ & ๕9.r & ะ १.६ & كلية الهندسة & $\varepsilon$. \\
\hline$v . .1$ & $\checkmark \wedge .1$ & $79 . r$ & الكندي & or & $1 \leqslant . \wedge$ & 90.8 & $T \leq . V$ & الفنون الجميلة & ؛ \\
\hline vi.9 & vi.1 & $v . . r$ & العلوية للولادة & or & 74.9 & TV.0 & 94.7 & الجامعة المستنصرية & $\varepsilon r$ \\
\hline IV.A & 79.9 & ४४. & ابن البيطار & $0 \leqslant$ & $\because 1 . v$ & $7 . . V$ & 7.0 & الجامعة العراقية & $\varepsilon r$ \\
\hline 10.9 & 74. & ro.r & للحبل الثوكي القف & $\infty 0$ & 09.1 & 01.9 & 09.9 & الإدارة واقتصاد بذذاد & $\varepsilon \varepsilon$ \\
\hline VI.r & $v \cdot . r$ & $v \cdot . r$ & الزهزاوي & 04 & OA.V & 09.9 & 09.7 & الإدارة اقتصاد & $\varepsilon 0$ \\
\hline TV. 9 & १४. & iv.r & ابن البلدي & ov & $\curlyvee \wedge . \&$ & 99.0 & १^.V & الجامعة التكنلوجية & $\leq 4$ \\
\hline $0 \leqslant .1$ & 00.4 & $0 \leqslant . \varepsilon$ & حماد شهاب & 01 & OV.V & 01.7 & 09.7 & معهد تكنلوجيا زعفرانية & $\leq v$ \\
\hline \multirow{2}{*}{\multicolumn{4}{|c|}{ 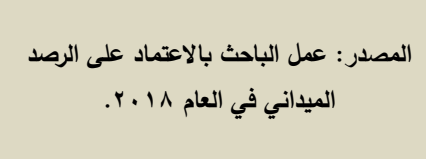 }} & & VY.r & $v 1.9$ & VY.Y & معهة الإدارة & $\leqslant 1$ \\
\hline & & & & & $0 \wedge .1$ & OV.A & $0 \wedge .6$ & القانون/مستنصربة & $\leqslant 9$ \\
\hline
\end{tabular}


المؤتمر العلمي الاولي الحادي عثر

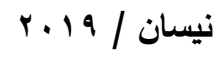

جامعة واسط

مجلــــة كليــــة التربيــــة

خامسا: التحليل المكاني والزماني للتلوث الضوضائي لأغلب مداخل المستشفيات في جانب الرصافة في مدينة بغداد حسب استعمالات الأرض في شهر تموز:--

يتبين من الجدول (مب) ان اعلى درجة لرصد الضوضاء بالنسبة لمداخل المستشفيات في الرصدة المسائية خلال شهر تموز وعلى مسافة ه. امتر كان عند مدخل مستشفى (الشيخ زايد) ويعود ذلك لك الى موقع المستشفى عند شارع رئيسي يتسم بحركة سير قويـة جدا، وعلى التتابع يعد مستشفى (حماد شهاب) للرصدة المسائية ويعود ذلك الى بعد المستشفى المذكور عن الشارع الدولي الرئيسي بين بغداد

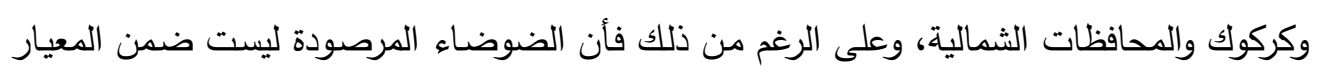
العالمي والمحلي المقبول للضوضاء. سادسا: التحليل المكاني والزماني للتلوث الضوضائي لأغلب الثوارع التجارية في جانب الرصافة في مدينة بغداد حسب استعمالات الأرض في شهر تموز:يتبين من الجدول (Tr) ان اعلى رصد للضوضاء لأغلب الشوارع التجارية في جانب الرصافة خلال شهر تموز في الرصدة المسائية كان لـ(شارع التوت) ويعود ذلك الى الزحام المروري للسيارات بسبب نشاط التسوق الكبير للأفراد الوافدين على الثارع المذكور واصوات المنبهات المذكورة، وعلى في التتابع فأن اقل رصد للضوضاء بالنسبة للشوارع التجارية كان لـشارع البنوك) وعلى الرغم من ذلك فأن مستوى الضوضاء المرصود ليس مطابق للمعايير العالمية والمحلية للضوضاء. • 
المؤتمر العلمي الدولي الحادي عثر

\begin{tabular}{|c|c|c|c|c|c|c|c|c|c|}
\hline \multicolumn{5}{|c|}{ 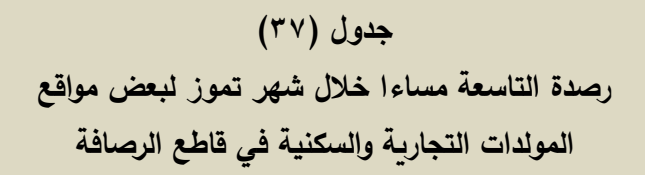 } & \multicolumn{5}{|c|}{ 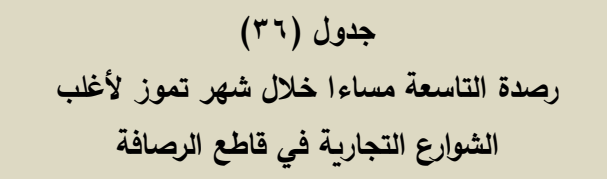 } \\
\hline 牙 & 可 & $\begin{array}{l}\overline{3} \\
\bar{s} \\
\overline{3}\end{array}$ & اسم الموقع & ت & 牙 & 牙 & $\begin{array}{c}\overline{3} \\
\bar{s} \\
\overline{3} \\
\bar{\jmath}\end{array}$ & اسم الموقع & ت \\
\hline IrY.A & Irr.r & Irr.r & الشعب & 79 & OV. \{ & $Y . . Y$ & $09 . r$ & شارع & ०9 \\
\hline $110 . r$ & 117.8 & $110 . r$ & مولدات & $v \cdot$ & $\curlyvee \wedge . \wedge$ & TV.ะ & 74.8 & فلسطين & 7. \\
\hline $\mid r \cdot . r$ & IYr.r & $|r| . r$ & مولدات & VI & $v \cdot . q$ & $v 1.9$ & $v \cdot . r$ & الجديدة & 71 \\
\hline $1 r \leq .7$ & I Yo.v & $\mid Y \leq . \varepsilon$ & مولدات & $V Y$ & V1.1 & $v \cdot . \varepsilon$ & $v . .0$ & شارع عدن & $7 Y$ \\
\hline 119.1 & Ir..o & $1 Y . .7$ & مولدات & $v r$ & TV.A & TV.Y & ४ง.r & شارع المكاتب & זי \\
\hline $11 v .1$ & 118.9 & $11 \wedge . v$ & مولدات البلديات & $V \leq$ & 79.9 & $v \cdot . r$ & 79.4 & شارع & $7 \varepsilon$ \\
\hline 117.4 & 110.7 & $110 . v$ & مولات القاهرة & vo & $V \varepsilon . r$ & vr.q & Vr.r & شارع & 70 \\
\hline $11 V . \varepsilon$ & 117.8 & 111.7 & مولدات & 14 & 7५. & 90.1 & 74. & شليخ & 79 \\
\hline IIV.r & IIV.r & $119 . r$ & مولدات & $v V$ & $V \varepsilon . r$ & vr.r & $V \varepsilon . Y$ & شارع التوت & IV \\
\hline داني في & 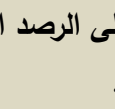 & عالاعتماد 1 ا. & عمل البا. & ل) & VI.r & vi.r & $v \cdot . r$ & شارع كرادة & 71 \\
\hline
\end{tabular}


المؤتمر العلمي الاولي الحادي عشر

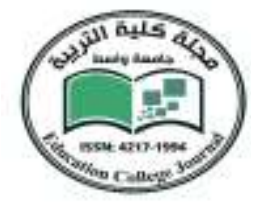

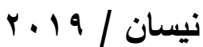

جامعة واسط

مجلــــة كليــــة التربيــــة

سابعا: التحليل المكاني والزماني للتلوث الضوضائي لبعض مواقع المولدات التجارية والسكنية في جانب الرصافة في مدينة بغداد حسب استعمالات الأرض في شهر تموز:يتبين من الجدول (rV) ان اعلى رصد للضوضاء بالنسبة لمواقع المولدات في جانب الرصافة وللرصدة المسائية كان لموقع مولدات (مدينة الصدر) وذلك بسبب زيادة سحب الطاقة الكهربائية للمنازل والاستخدامات الأخرى بفعل عمليات التبريد التي يتطلبها الموسم الحار اثناء وقت الرصد والتشغيل الليلي للمولدات في ساعة الرصد والتي تستمر حتى الصباح الباكر، وعلى التتابع فأن اقل المواقع رصدا للضوضاء في جانب الرصافة كان لموقع مولدات (القاهرة) وعلى الرغم من ذلك فأن المولدات تعد اكثر المواقع المرصودة تلوثا ضوضائيا من بين الاستخدامات الأخرى والتعرض لها لمدة طويلة يسبب امراضا مزمنة ومنها مرض السكري، وهي بالطبع ليست ضمن المعيار العالمي

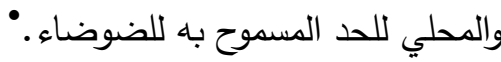
ثامنا: التحليل المكاني والزماني للتلوث الضوضائي لبعض مواقع المدارس المتنوعة في جانب الرصافة في مدينة بغداد حسب استعمالات الأرض في شهر تموز:يتبين من الجدول (^^) ان اعلى رصد للضوضاء في شهر تموز خلال الرصدة المسائية بالنسبة لمواقع المدارس في جانب الرصـافة كان لمرقع مدرسة (ثانويـة في مدينـة الصدر) ويعود ذلك الى ان المنطقة التي تقع بها المدرسـة هي منطقـة ذات كثافة سكانية عاليـة اذا مـا قورنت بالمسـاحة التي

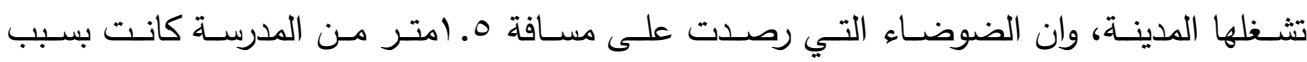
الضوضـاء الناتجة عن أصوات مرافقة بالنسبة للموقع المذكور وليس بسبب الضوضـاء الصسادرة من المدرسة ذاتها، وعلى الترتيب فأن اقل المواقع التعليمية رصدا للضوضـاء خلال الزمان والمكان ذاته لــ(السرور/الحسينية) ويعود ذلك الـى بعد المدرسـة المذكور عـن اغلب مصـادر ضوضـاء المدينـة وتمركزها بين أمـاكن سكن الافراد، وبعدها عن الشوارع التجاريـة الرئيسية وعن مراكز التسوق وعن

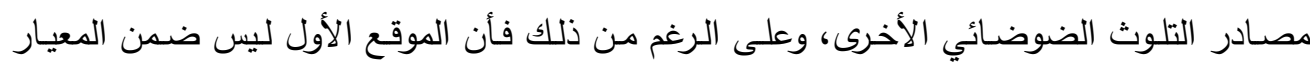
العالمي والمحلي للصحة العراقية بالنسبة لمستوى الضوضاء المسموح به، على عكس الموقع الأخير الذي هو ضمن المعيار المسموح للضوضاء. • 
المؤتمر العلمي الدولي الحادي عشر

\begin{tabular}{|c|c|c|c|c|c|c|c|c|c|}
\hline \multicolumn{6}{|c|}{ رصدة التاسعة مساءا خلال شهر تموز لبعض المواقع الترفيهية في قاطع } & \multicolumn{4}{|c|}{ 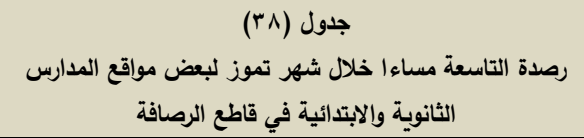 } \\
\hline 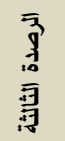 & 亨 & $\begin{array}{c}\overline{3} \\
\text { s. } \\
\overline{2} \\
\overline{3}\end{array}$ & اسم الموقع & 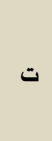 & 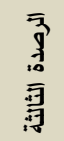 & 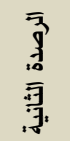 & 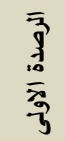 & اسم الموقع & $=$ \\
\hline Vr. & Vr.r & VY.Y & مدينة العاب السندباد & $\wedge \wedge$ & ro.q & $r 0.9$ & r..r & ث.المعالي/بغداد الجديدة & $\vee \wedge$ \\
\hline$V r .9$ & $v \varepsilon . v$ & Vr.r & مدينة العاب بذاد & $\wedge 9$ & ro.r & $r \leq .1$ & 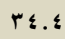 & أ.الخليج/منطقة الدرويش & vq \\
\hline$\varepsilon 9 . r$ & $\varepsilon 9.1$ & $\varepsilon 9.9$ & الجزيرة السياحية & 9. & r४. & rv.\& & rv.v & ث.الخساء شارع الربيعي & $\wedge$. \\
\hline 1.. & ד.r & $r . r$ & حديقة بيت طبرة & 91 & r५.० & r..1 & $r 0.1$ & ث.الاصمعي/الثبب & $\wedge$ \\
\hline V^.A & Va.६ & Va.9 & كوفيات ومقاهي & ar & 01.9 & 01.1 & or.r & م.طوعة/الحسينية & Ar \\
\hline VA.r & VV. & VA.r & فلسطرين شارع & $9 \mathrm{~T}$ & ri.\& & $r \cdot . \wedge$ & $r \cdot . r$ & أ.السرور/الحسينية & Ar \\
\hline V^.1 & vv.v & VA.1 & كورنيش إيليا & $9 \leqslant$ & ๕.$\vee V$ & $\{0.4$ & $\leq 0 . r$ & ث.المهندسين/المهنسسين & $\wedge \varepsilon$ \\
\hline VV. 9 & VA.r & vV.v & ومقاهي متفرقة & 90 & $\leq 9 . r$ & $\varepsilon \wedge . \varepsilon$ & $\leqslant 9.9$ & ث.صليخ/صليخ & 10 \\
\hline \multirow{2}{*}{\multicolumn{5}{|c|}{ المصدر: عمل الباحث بالاعتماد على الرصد الميداني في العام }} & $0 . \mu$ & $0 \varepsilon . r$ & 00.0 & أبتدائية/مدينة الصدر & 14 \\
\hline & & & & & ๑५.r & 00.1 & 04.7 & ثثانوية/مدينة الصدر & AV \\
\hline
\end{tabular}

تاسعا: التحليل المكاني والزماني للتلوث الضوضائي لبعض البون المواقع الترفيهية في جانب الرصافة في مدينة بغداد حسب استعمالات الأرض في شهر تموز :-

يتبين من الجدول (99 ان اعلى رصد للضوضاء بالنسبة للمواقع الترفيهية في شهر تموز خلال

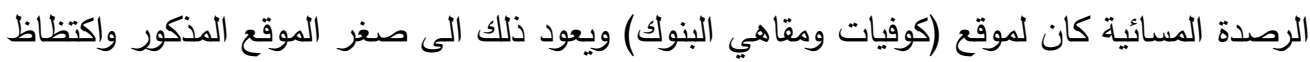

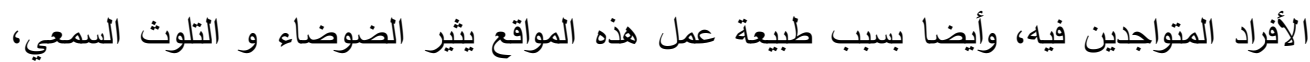

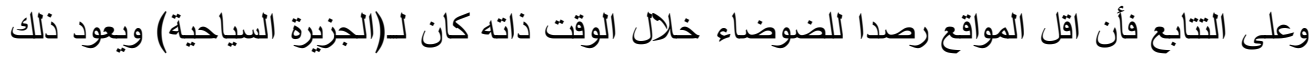

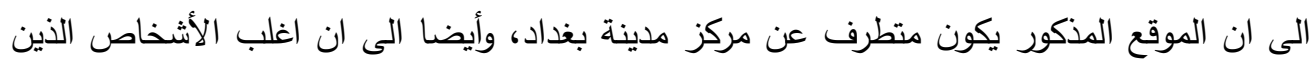

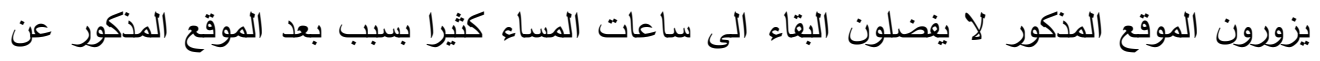

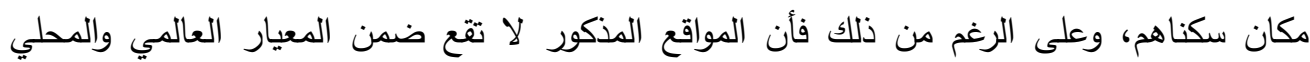
للصحة العراقية لمستوى الضوضاء المسموح بهاه. 
المؤتمر العلمي الاولي الحادي عثر

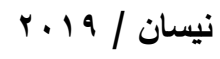

جامعة واسط

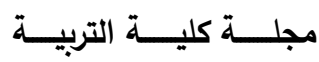

عاشـرا: التحليـل المكاني والزمـاني للتلوث الضوضـائي لبعض مواقع التسـوق المحليـة في جانب

الرصافة في مدينة بغداد حسب استعمالات الأرض في شهر تموز:-

يتبين من الجدول (• \&) ان اعلى رصد للضوضاء بالنسبة لمراكز التسوق المحلي خلال الرصدة

المسائية في شهر تموز لموقع سوق (بغداد الجديدة) ويعود ذلك المستوى المرتفع للضوضاء ليس الى طبيعـة عمل مراقع التسوق المذكورة وانما الى ان مكان السوق المذكور الذي يكون مجاور لشـارع رئيسي وتجاري نشط جدا في النهار ويستخدم ليلا لعودة اعلب العاملين من والى الموقع المذكور وأيضا من والى أماكن سكناهم، فطبيعة الحركة النشطة للمارة تسبب رصدا للضوضاء، وعلى التوالي فأن اقل المواقع رصدا للضوضاء بالنسبة لمواقع التسوق المحلي كان لـ(سوق الفحامة) وسبب تسجيلها اقل رصد للضوضاء بسبب موقع مركز التسوق المذكور الذي يعد من ضمن اطراف جانب الرصافة، وأيضـا قلة الوافدين اليهه حتى في النهار الذي يقتصر على سكان المدينة التابع لها، وان مستوى لهـ الضوضـاء المرصود يقع ضمن المعيار العالمي للضوضـاء لكلا الموقعين و معيار الصحة العراقية

للضوضاء ليلا. 
المؤتمر العلمي الاولي الحادي عثر

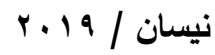

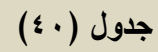

رصدة التاسعة مساءا خلال شهر تموز لبعض مواقع التسوق المحلية في قاطع الرصافة

\begin{tabular}{|c|c|c|c|c|}
\hline 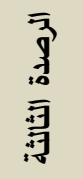 & 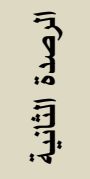 & $\begin{array}{l}\overline{3} \\
\overline{3} \\
\overline{3} \\
\text { दे }\end{array}$ & اسم الموقع & ت \\
\hline$r . .1$ & $r . r$ & rq.9 & سوق الفحامة & 97 \\
\hline 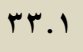 & rr.r & rr.r & سوق الراشدية & $9 V$ \\
\hline พч. & mч. & r.. & سوق ؛ الالاف & 91 \\
\hline$\leqslant r . v$ & $\leq 0 . r$ & ؛ $\leqslant . \varepsilon$ & سوق بغداد الجديدة & 99 \\
\hline$r 0.9$ & r५.9 & rч.^ & سوق مدينة الصدر & $1 \ldots$ \\
\hline$r \leq . \Lambda$ & $r \leq . V$ & $r \leq . \varepsilon$ & سوق باب المعظم & 1.1 \\
\hline พч.1 & ro.q & r..7 & سوق الحسينية & $1 \cdot r$ \\
\hline
\end{tabular}


المؤتمر العلمي الاولي الحادي عثر

ن بيسان / 19

\section{جامعة واسط}

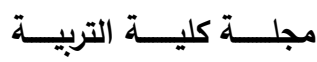

المصادر :

Ditrich schwela, World Health Organization Guidelines on Community Noise,TRB

Session 391 Setting an Agenda for Transportation Noise Management Policies in the United States ,10 January 2001,Washing DC.USA,P.10.

المصدر : جمهورية العراق ، ملاحق اللائحة التنفيذية للقانون رقم (ع) لسنة ع9 99 في شأن البيئة ، (مستبلة بالقرار

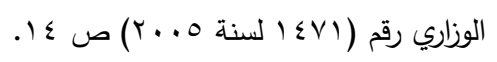

• مستوى الضوضاء العالمي WHO في تقاطعات الطرق · ـــ · ج وحسب المعيار المحلي لوزارة الصحة العراقية -30

60

• حسب المعيار العالمي WHO لمناطق عبور الجسور 0 ؛ ــ 7

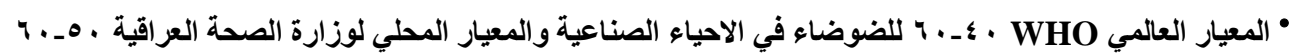

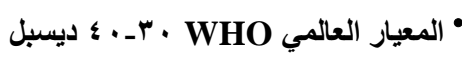

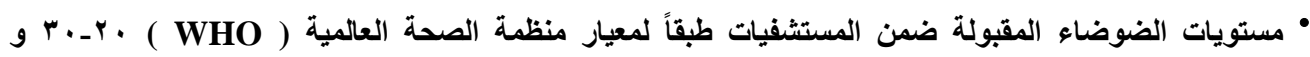

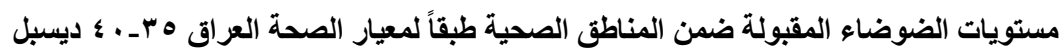

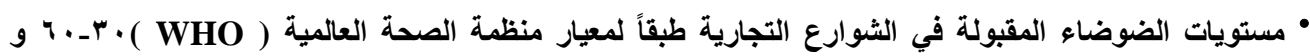

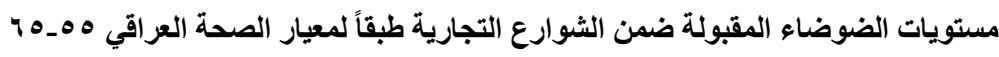

• مستويات الضوضاء المقبولة ضمن مناطق المكائن المتعدد الاستعمال طبقاً لمعيار منظمة الصحة العالمية WHO ) ( هـ ـهـ و مستويات الضوضاء المقبولة للضوضاء للاستعمالات المتنوعة المولدات انموذجا طبقاً لمعيار الصحة

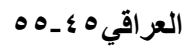

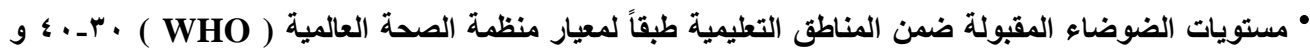

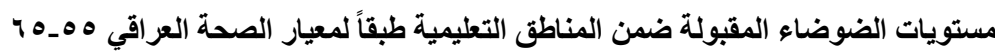


المؤتمر العلمي الاولي الحادي عشر

• مستويات الضوضاء المقبولة ضمن الاستخدامات الترفيهية طبقاً لمعيار منظمة الصحة العالمية )

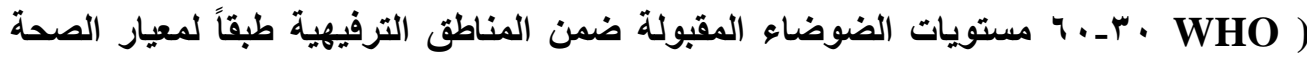

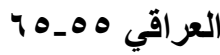

• مستويات الضوضاء المقبولة ضمن مناطق التسوق طبقاً لمعيار منظمة الصحة العالمية ( WHO ) • - • ؟ و

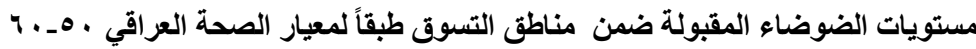

• مستويات الضوضاء المقبولة ضمن تقاطعات الطرق طبقاً لمعيار الصحة العراقي ه ــهـ.

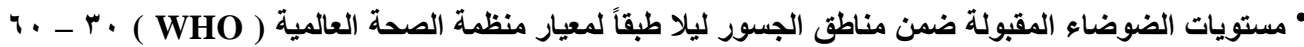
مستويات الضوضاء المقبولة للجسور ليلا طبقاً لمعيار الصحة العراقي هـ - ه ؛ ؛.

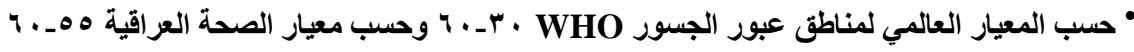
• الضوضاء المقبولة في الاستخدامات التعليمية حسب المعيار العالمي WHO · بـ - ـ ديسبل

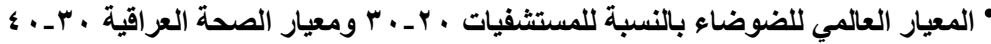

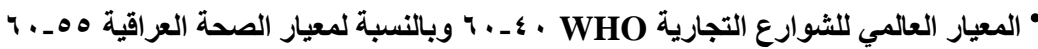

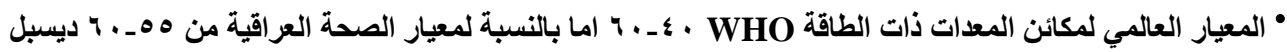

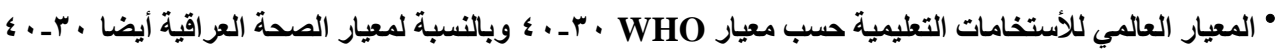

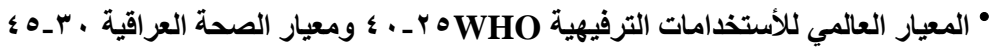

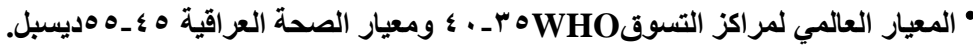

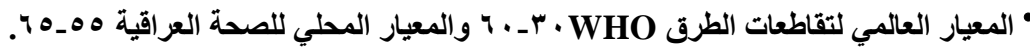

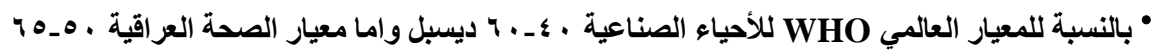

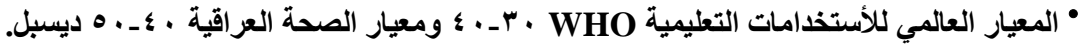

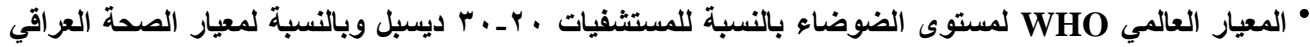
. $\leqslant 0-r 0$

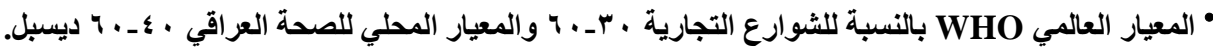

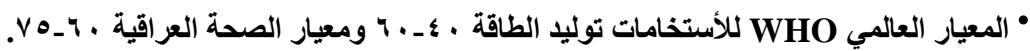


المؤتمر العلمي الاولي الحادي عشر

• المعيار العالمي للأستخدامات التعليمية WHO · بـ · ؛ ومعيار الصحة العراقي • ـ ـهـ.

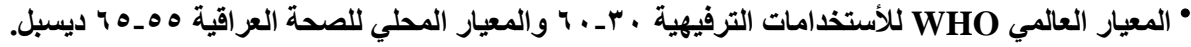

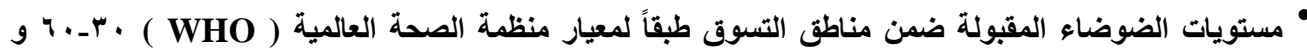

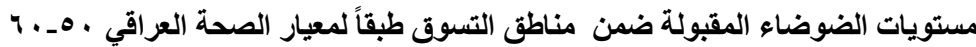
• مستويات الضوضاء المقبولة ضمن مناطق التسوق طبقاً لمعيار منظمة الصحة العالمية ( WHO ) . r- • ' و و مستويات الضوضاء المقبولة ضمن مناطق التسوق طبقاً لمعيار الصحة العراقي ــــ

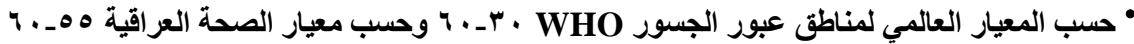

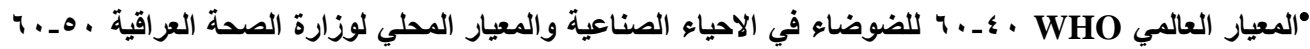
ديسبل.

•الضوضاء المقبولة في الاستخدامات التعليمية حسب المعيار العالمي WHO • بـ • • ديسبل

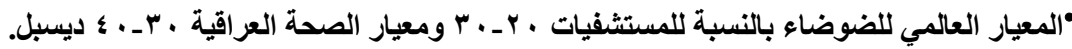

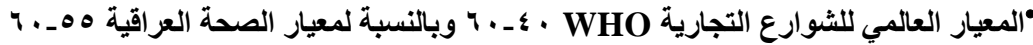

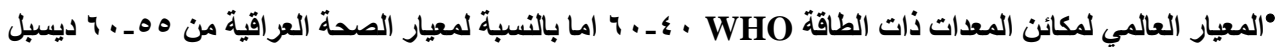

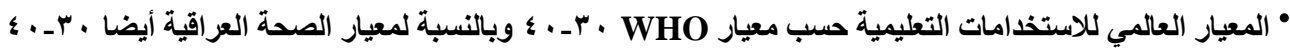

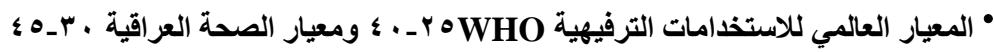
•المعيار العالمي لمستوى الضوضاء بالنسبة لمراكز التسوقWHO ه rـ . ؛ ومعيار الصحة العراقية ه ؛ ـه هديسبل. 